\title{
Western Corn Rootworm, Plant and Microbe Interactions: A Review and Prospects for New Management Tools
}

\author{
Kyle J. Paddock ${ }^{1}\left(\mathbb{D}\right.$, Christelle A. M. Robert ${ }^{2,3}\left(\mathbb{D}\right.$, Matthias Erb $^{2,3}$ (D) and Bruce E. Hibbard $4, *(\mathbb{D})$ \\ 1 Division of Plant Sciences, University of Missouri, Columbia, MO 65211, USA; paddockk@mail.missouri.edu \\ 2 Institute of Plant Sciences, University of Bern, 3013 Bern, Switzerland; \\ christelle.robert@ips.unibe.ch (C.A.M.R.); matthias.erb@ips.unibe.ch (M.E.) \\ 3 Oeschger Centre for Climate Change Research, University of Bern, 3013 Bern, Switzerland \\ 4 Plant Genetics Research Unit, United States Department of Agriculture, Agricultural Research Service, \\ Columbia, MO 65211, USA \\ * Correspondence: bruce.hibbard@usda.gov
}

Citation: Paddock, K.J.; Robert, C.A.M.; Erb, M.; Hibbard, B.E. Western Corn Rootworm, Plant and Microbe Interactions: A Review and Prospects for New Management Tools. Insects 2021, 12, 171. https:// doi.org/10.3390/insects12020171

Academic Editors: Lance J. Meinke and Joseph L. Spencer

Received: 22 January 2021

Accepted: 13 February 2021

Published: 17 February 2021

Publisher's Note: MDPI stays neutral with regard to jurisdictional claims in published maps and institutional affiliations.

Copyright: (c) 2021 by the authors. Licensee MDPI, Basel, Switzerland. This article is an open access article distributed under the terms and conditions of the Creative Commons Attribution (CC BY) license (https:// creativecommons.org/licenses/by/ $4.0 /)$
Simple Summary: Over 90 million acres of US cropland are planted with corn, Zea mays, annually. The western corn rootworm, Diabrotica virgifera virgifera, causes significant economic damage by feeding on corn roots and the insect has populations that have adapted to nearly all management techniques in some regions. Additional tools are needed. Significant research on the basic biology of this pest has added new possibilities. Here, we summarize research that we believe has potential for future management of this major pest.

Abstract: The western corn rootworm, Diabrotica virgifera virgifera LeConte, is resistant to four separate classes of traditional insecticides, all Bacillius thuringiensis $(\mathrm{Bt})$ toxins currently registered for commercial use, crop rotation, innate plant resistance factors, and even double-stranded RNA (dsRNA) targeting essential genes via environmental RNA interference (RNAi), which has not been sold commercially to date. Clearly, additional tools are needed as management options. In this review, we discuss the state-of-the-art knowledge about biotic factors influencing herbivore success, including host location and recognition, plant defensive traits, plant-microbe interactions, and herbivore-pathogens/predator interactions. We then translate this knowledge into potential new management tools and improved biological control.

Keywords: Western corn rootworm; belowground herbivory; pest management strategies; push-pull; plant defenses; biological control; soil health

\section{Introduction}

Management of the western corn rootworm (Diabrotica virgifera virgifera LeConte) in maize cropping systems has a long, complex history. After its discovery as a pest of corn in 1909 [1], western corn rootworm (WCR) populations rapidly expanded eastward as corn was planted, reaching New England and, more recently, through multiple establishments and subsequent spread, European regions [2-4]. Annual costs of damage due to yield loss and management practices are estimated to be over $\$ 2$ billion in the United States [5]. A diversity of management options exists [6], but management has been complicated by the continual adaptation of WCR to control tactics. WCR have developed resistance to four separate classes of traditional insecticides, all Bt toxins currently registered for commercial use, crop rotation, and even to dsRNA and innate plant resistance traits [7-17]. In some regions of Europe, management options are even more limited as use of transgenic maize producing Bt targeting rootworms are restricted, and limitations have been placed on neonicotinoids [18].

New tools for sustainable and economical management of this elusive pest are crucially needed. In this review, we highlight the status and potential of several prospective tools 
based on recent advances in the understanding of the biology and chemical ecology of the pest. These tools include push-pull strategies, plant defenses and nutrition, beneficial plant-microbial partners, and microbial control agents.

\section{Disrupting WCR Establishment}

Considerable efforts investigating the chemical ecology of maize-rootworm interactions have illuminated complex mechanisms, including physical and chemical processes, involved in host plant attraction, recognition, and in feeding stimulation. WCR larvae hatch in spring from eggs laid in the previous year. The period between eclosion and host plant establishment is critical for WCR. It is estimated 95\% of hatching larvae die before establishment, but the factors responsible for high mortality remain unknown [19-21]. Physical and chemical factors have been demonstrated to affect first-instar larval movement and host plant establishment. Larval movement is limited with increasing soil bulk density $[22,23]$ with first instar larvae traveling farther in finer textured soils compared to more coarse textured soils [24]. Increased egg distance to maize roots can limit root damage and adult emergence [25]. Questions still remain as to why most viable eggs fail to produce established larvae. For example, it is unknown the extent to which first-instar larvae can burrow through soil and instead rely on pre-existing soil pores and air channels [26]. If this major mortality factor was better understood, it might be possible to manipulate it for management.

It may also be possible to utilize knowledge of the factors influencing host plant establishment for management in the future. WCR larvae orient towards maize roots following $\mathrm{CO}_{2}$ gradients and can detect concentrations as low as $2 \mathrm{mmol} / \mathrm{mol}$ [27-29]. In choice tests, significantly more neonate WCR larvae were attracted to synthetic $\mathrm{CO}_{2}$ with a concentration of $11.2 \mathrm{mmol} / \mathrm{mol}$ than to growing maize with a $\mathrm{CO}_{2}$ concentration of $1.36 \mathrm{mmol} / \mathrm{mol}$ [29]. Encapsulated $\mathrm{CO}_{2}$ sources were tested as a means to confuse western corn rootworm larvae. The treatment resulted in significantly less damage than untreated controls and resulted in damage similar to a soil insecticide control [30]. $\mathrm{CO}_{2}$ has also been evaluated with insecticides in an attract-and-kill approach [31]. However, neither approach has been adopted by industry. Other volatiles, including $(E)-\beta$-caryophyllene and ethylene, can also be detected and used by the WCR to locate suitable hosts [32]. For instance, (E)- $\beta$-caryophyllene can be used as a cue to orient towards roots attacked by conspecific larvae and to aggregate in a density-dependent manner [33]. (E)- $\beta$-caryophyllene does not attract neonates [34], so its usefulness as a volatile to confuse WCR larvae in the field remains unclear.

Once maize roots are located, larval feeding is triggered by host recognition cues. Strnad and Dunn [35] were the first to document the existence of host recognition factors. One such recognition factor was isolated [36] and identified by Bernklau et al. [37] as monogalactosyldiacylglycerol (MGDG). Bernklau et al. [37] discovered that the proportion of larvae exhibiting the tight-turning behavior elicited by MGDG was higher for larvae exposed to MGDG-saturated discs previously fed upon by WCR larvae. The authors concluded that WCR larvae were responding to byproducts of MGDG breakdown in addition to MGDG itself, which generates questions in regard to salivary enzymatic functions and plant-insect interactions involving WCR. Previously, Bernklau and Bjostad [38] isolated and identified a blend of glucose $(30 \mathrm{mg} / \mathrm{mL})$, fructose $(4 \mathrm{mg} / \mathrm{mL})$ and sucrose $(4 \mathrm{mg} / \mathrm{mL})$ plus linoleic or oleic acid $(0.3 \mathrm{mg} / \mathrm{mL})$ as feeding stimulants for WCR larvae. Subsequent investigations revealed sucrose to be the preferred sugar of WCR larvae [39]. The addition of free fatty acids to feeding blends significantly increased staying behavior of larvae, but high concentrations were toxic [40]. In addition to primary metabolites, complexes between micronutrients and maize secondary metabolites shape the foraging behavior of the WCR within a root system [7,41]. Specifically, complexes between soil iron (Fe) and the exuded 7-O-methylated, N-hydroxylated benzoxazinoid (DIMBOA) elicited WCR feeding preferences [41]. Interestingly, the application of the $\mathrm{Fe}(\mathrm{III})(\mathrm{DIMBOA})_{3}$ complex on rice or barley, two non-host plant species for the WCR, was sufficient to trigger WCR feeding [41]. 
Experiments with benzoxazinoid-deficient plants and WCR larvae with impaired capacities to detect sugars confirmed the importance of the individual and combined cues for WCR foraging, but also revealed considerable WCR robustness to disruption of individual cues [42]. This may complicate attempts to use single cues for foraging disruption. Plant roots also produce compounds that repel foraging WCR larvae. Bernklau et al. [43] identified that small amounts ( $1 \mathrm{ug}$ ) of methyl anthranilate could prevent WCR larvae from approaching $\mathrm{CO}_{2}$ sources and maize roots. Although the identification of compounds involved in feeding stimulation and staying behavior are useful, a suite of compounds is likely at play, as responses to crude maize extracts are generally stronger.

This basic understanding of attraction, recognition, and feeding stimulation could be utilized to improve existing management strategies or aid the development of alternative control tactics. Strategies such as (i) fine-tuning the production of cues involved in WCR attraction, establishment, and feeding, (ii) combining attractants with pesticides, or (iii) using attractant and repellent chemicals in push-pull programs should be considered. Manipulating the production of attractants, recognition factors, or feeding stimulants remains a very delicate avenue for pest management. One should carefully consider the impact of any shifts in primary or secondary plant metabolites on the plant and their interactions with the environment. For instance, because maize plants use $\mathrm{Fe}(\mathrm{III})(\mathrm{DIMBOA})_{3}$ complex for iron uptake and benzoxazinoids for protection against generalist herbivores, disrupting the benzoxazinoid pathway for WCR management could potentially have significant consequences on plant growth and yield, as well as on herbivore outbreaks [44]. The application of attractant volatiles can disrupt host location and, in turn, establishment and damage by the WCR. $\mathrm{CO}_{2}$-generating materials are strong enough to disrupt the host-location ability of WCR larvae and significantly reduce damage under laboratory and field conditions [30]. Combining attractant cues with pesticides has been reported to be extremely effective in a laboratory setting. For example, Bernklau et al. [45] increased insecticidal activity of thiamethoxam by 10,000-fold when added to a feeding stimulant blend. The addition of 6-methoxy-2-benzoxazolinone (MBOA) to insecticides also improved field activity [46]. Adding host recognition cues, feeding stimulants, $\mathrm{CO}_{2}$, or other attractants to insecticides could increase efficacy and perhaps even provide a "pull" factor for a push-pull management strategy [47]. Bernklau et al. [48] documented that methyl anthranilate acts as a repellent for foraging WCR larvae in soil. Methyl anthranilate-saturated carriers could be placed in-row with maize seedlings and function as a "push" factor away from roots. Similarly, susceptible corn with repellent seed treatments could be used in conjunction with high-dose transgenic corn treated with attractants and/or feeding stimulants. Push-pull strategies have been used successfully in pest management with other crop systems [47].

\section{Selecting for Maize Lines with Effective Defenses against WCR}

Selecting for plant natural defenses to insects has been a successful management strategy for many pests, with hundreds of insect-resistant crop cultivars grown around the world $[49,50]$. Plant defenses include resistance and tolerance traits. Resistance traits allow plants to reduce herbivore damage [51,52] and are further categorized into antibiosis and antixenosis. Antibiosis refers to a reduction in growth and/or reproduction of the insect due to feeding on a resistant plant, whereas antixenosis limits damage to the host plant by decreasing the attractiveness of the host as food or shelter. Resistance traits might involve structural changes (root architecture, lignin content, trichomes) or production of allelochemicals (tannins, alkaloids, glucosinolates) [49,53-55]. Tolerance traits allow the plant to maintain productivity in spite of sustaining damage [56]. Tolerance to root herbivores, for instance, includes changes in photosynthesis, resource reallocation, and delayed compensatory growth [57-60].

Public breeding efforts to develop or select plant defenses to WCR have been intermittent for the past 85 years (Table 1) [61-114]. Initial breeding programs began in response to observations that different maize strains varied in their response to WCR pressure [61,62]. In recent breeding programs, selection for resistant and tolerant strains of maize has been 
based on several criteria. These criteria include plant lodging, vertical pull resistance, and yield, which serve as indirect measures of WCR damage. Root damage ratings and WCR survival provide an estimate of antibiosis and/or antixenosis capacity. Root size and root regrowth, although influenced by environmental factors, provide an estimate of tolerance to WCR damage. Early resistant hybrids (1980s) had larger roots and experienced lower levels of lodging upon WCR feeding [80]. More recently, several germplasm lines with mechanisms of resistance beyond tolerance have been identified [75,85,92,94,99,100,104,113]. Hibbard et al. [94] released CRW3(S1)C6 that had damage ratings not significantly different than a Cry3Bb1 hybrid when crossed to an elite inbred line. El Khishen et al. [99] and Bernklau et al. [100] clearly documented that the commercial maize hybrids SUM2162 and SUM2068 had relatively strong antibiosis resistance. Unfortunately, these hybrids did not compete with elite hybrids for yield when rootworm pressure was lacking, and at this time, there are no commercially available hybrids providing natural and effective host plant resistance or tolerance to WCR.

Table 1. Breeding efforts to develop native plant defense to the western corn rootworm over the past 85 years.

\begin{tabular}{ccc}
\hline Years & Location & References \\
\hline $1935-1945$ & Illinois Natural History Survey & {$[61,62]$} \\
\hline $1970-2007$ & Iowa State University & {$[63,64,73,84,95,106,108-112]$} \\
\hline $1963-2010$ & USDA-ARS, Brookings, South Dakota & {$[65-72,74-81,113]$} \\
\hline $1990-1997$ & University of Ottawa & {$[82,83,85-89]$} \\
\hline 1992-present & USDA-ARS, Columbia, MO & {$[90-94,96-100]$} \\
\hline 1995-present & University of J. J. Strossmayer & {$[101-104,114]$} \\
\hline 2002-present & University of Illinois-Champaign & {$[105,107]$} \\
\hline
\end{tabular}

Genomic work in maize has revealed a bounty of natural diversity across germplasm lines [115]. Screening of landraces, populations, and inbreds by insect-resistance breeding programs has revealed that genetic bins containing insect resistance quantitative trait loci (QTLs) are widespread, likely meaning there is great complexity and diversity in maize responses to herbivores [116]. However, because much of the work of insect-resistance breeding programs has focused on stem and leaf feeding traits, confirmed resistance against leaf herbivores is more prevalent than resistance to root feeding insects. This does not necessarily exclude these QTLs from conferring resistance to root-feeding insects. Recent work from Bohn et al. [107] revealed that QTLs associated with differences in root damage by WCR overlapped with QTLs involved with insect resistance previously identified by Meihls et al. [116]. Many of these QTLs (chromosome 1, 3, 6-10) contained gene/genes predicted to code for proteins involved in L-ascorbate and (E)- $\beta$-caryophyllene biosynthesis, in addition to the detoxification of reactive oxygen species. Investigations by Brkić et al. [114] found chromosome 1 and 6 contain several QTLs for maize resistance to WCR. Studies investigating the QTL regions previously described may provide a knowledge base for breeding programs aimed at increasing maize native resistance to WCR. Specifically, the QTLs correlated with resistance to WCR were located in the same genomic bins as two previously described insect resistance genes, aoc1 (bin 1.04) and mir1 (bin 6.02). mir1 encodes an insecticidal protease, Maize Insect Resistance 1- Cysteine Protease (MIR1-CP), that can disrupt the peritrophic matrix of caterpillars and even act synergistically with Bt toxins $[117,118]$. Separate investigations have revealed mir1 expression increases upon WCR feeding in the inbred Mp708 [119]. In addition, transcript levels of several defense genes (tps23, fpps3, rip2, mpi) significantly increased in conjunction with jasmonic acid (JA) levels, potentially contributing to reduced larval recovery and reduced root damage [119]. Unfortunately, Castano-Duque et al. [119] did not utilize resistant and susceptible maize controls, so it is unclear how well this resistance would translate into a field setting. Other 
data suggest Mp708 is highly susceptible to natural rootworm feeding in the field (BEH, unpublished data). Given the high degree of WCR host adaptation, we estimate that the efficacy of generalized defense traits present across most commercial maize lines have limited potential to serve as WCR resistance factors.

As mentioned above, there are no publicly available hybrids conferring natural resistance or tolerance to WCR damage. The lack of correlation between inbred performance and hybrid performance [98] likely has contributed to this. Genotype-by-environment interaction (GEI) is high for natural rootworm resistance, resulting in low heritability of traits [107]. Likely contributing to GEI variability are differences in methodology. Infestation levels (natural variability vs. artificial) can generate high amounts of variation between environments and drown out trait effects. The paucity of effective natural defenses against WCR in commercial hybrids could also be a function of private breeding programs largely controlling for the pest via crop rotation or soil insecticides in their yield trials. This effectively removed the selection pressure and potentially decoupled yield and WCR tolerance/resistance traits. In contrast, seed industry yield trials rarely control for herbivores such as the European corn borer, Ostrinia nubilalis (Hübner), and therefore indirectly increase tolerance to this pest over time (James Bing, Corteva, personal communication). Despite the lack of current resistant and/or tolerant hybrids available to growers, native resistance traits from exotic sources likely do have potential to improve WCR management. Full genome sequencing and improved breeding methods coupled with modern gene editing technologies examining direct effects of specific gene/genes involved with defensive traits could potentially increase the speed and efficiency of elite cultivar development with native plant defense [120]. Ultimately though, the success relies on investing time in screening these plants for their capacity to cope with WCR damage.

\section{Altering Maize Nutritional Value for the WCR}

The nutritional dimension of WCR biology is central to management, but research efforts to understand this aspect have been intermittent. Assessing chemical profiles of host and non-host plant species may allow determination of key compounds or compound blends involved in WCR nutrition. Branson and Ortman [121,122] observed larval survival for at least 10 days on grass species. WCR neonates developed to the second instar on 18 of 44 grass species screened, whereas no larvae developed on any of the 27 broadleaf species screened. Clark and Hibbard [123], Oyediran et al. [124], and Wilson and Hibbard [125] further refined the host range of WCR larvae. Moeser and Vidal [126] developed a food conversion index to evaluate alternate hosts and several maize varieties. Selecting for maize lines possessing some key characteristics of non-host plants may limit WCR damage in the field.

Evaluating WCR larval ability to pupate and to emerge as adults when feeding on maize plants of different ages showed promising results. WCR consume root resources near where they initially establish, before moving to larger, more nutritious nodal roots that form on the side of the stalk [7,22]. Not only do later instar larvae prefer younger, nodal roots, but larvae require these younger roots for proper development [127]. Hibbard et al. [127] conducted greenhouse and field trials to determine what root phenology was optimal for the establishment and development of WCR larvae. In the field, plants were infested weekly with WCR eggs starting on the initial planting date and continuing until plants matured to $\sim$ V13 [128]. As predicted, plant damage gradually decreased with later infestation dates, because larger root systems can better withstand attack. Interestingly, larval recovery did not differ between infestation dates, but adult emergence did. Significantly fewer adults emerged from later infestation dates, suggesting larvae can establish on late vegetative stage (V13) plants, but nutrition is insufficient to produce adults. Given that WCR larvae perform poorly in the absence of Fe(III)(DIMBOA) ${ }_{3}$ complexes and that DIMBOA is mostly exuded by young node roots of young plants $[7,41]$, it is tempting to speculate that iron, known to be an essential micronutrient for insects [129], and/or DIMBOA are key factors in limiting WCR development to adulthood. Results from alternative host plant species 
also point towards nutritional inadequacies of mature plants [130]. Further understanding of WCR nutritional requirements to successfully achieve pupation may allow selection for plants that do not support WCR larval development to adults.

Further efforts to understand the nutrition requirements of WCR larvae have resulted in the development of artificial diets [131]. Current efforts to improve artificial diet further are focused on understanding the metabolomic responses to maize, in addition to good and poor artificial diets (Huynh et al., unpublished). If successful in gaining this understanding, reverse engineering maize varieties with roots of poor nutritional quality may also be possible. Changing such traits is typically accompanied by large pleiotropic effects, as herbivore nutrients also serve essential roles in plants. Thus, such approaches should try to disrupt WCR nutrition without impairing plant vigor; strategies to reach this aim are currently not in place.

\section{Plant-Mediated RNA Interference}

RNA interference (RNAi) is a biological response to double-stranded RNA (dsRNA) that triggers sequence-specific gene silencing [132]. This conserved machinery is present in many eukaryotes, including insects [133]. Silencing essential genes in insects can reduce herbivore damage and survival [134-139].

Baum et al. [140] and Bolognesi et al. [141] characterized the mechanism of action of dsRNA in WCR larvae. Baum et al. [140] identified 125 genes whose silencing led to significant WCR mortality. From these 125 genes, 14 caused mortality in 50\% $\left(\mathrm{LC}_{50}\right)$ of WCR at doses lower than $5.2 \mathrm{ng}$ dsRNA $/ \mathrm{cm}^{2}$ of artificial diet. These genes included putative $V$-ATPase A and D subunits, ESCRT I Vps28, III Vps2, and III Snf orthologs, a $\beta$-subunit of a COPI coatomer, ribosomal proteins, a proteosome ortholog, $\alpha$-actin, tubulin, and an RNA polymerase II ortholog [140]. Adult WCR exhibit similar responses to orally ingested dsRNA. Using artificial diet overlaid with dsRNA targeting $V$-ATPase subunit A, Rangasamy and Siegfried [142] successfully knocked down gene expression in adults and achieved significant mortality in 14 days. Knockdown of the gene target Sec23 resulted in significant mortality in adults after only six days of feeding [143]. Additional gene targets have successfully altered adult gene expression, specifically ones targeting genes involved in reproduction such as the chromatin remodeling gene brahma (brm), and the gap gene hunchback (hb) [144,145]. Eggs from RNAi targeted adults also experience downregulation of targeted genes, which could provide transgenerational control [144]. RNAi is now routinely used to identify key genes regulating WCR survival and fitness [41,144,146,147].

Transgenic maize plants using RNAi exhibit enhanced protection against WCR larvae when targeting essential genes such as $\alpha$-tubulin gene, $V$-ATPase subunits $\mathrm{A}$ and $\mathrm{C}$ genes, an intracellular protein trafficking pathway gene $s n f 7$, a subunit of the coat protein complex II Sec23, and a midgut expressed gene ssj1 [140,141,143,147,148]. In addition, Niu et al. [149] demonstrated the potential for WCR management by silencing genes involved in female fecundity. Using transgenic plants to silence the Boule (Dvbol) gene in WCR larvae resulted in reduced egg production and egg hatchability in adults [149]. Yet, Khajuria et al. [16] demonstrated the ability of the WCR to adapt to RNAi. WCR selected on DvSnf7 dsRNA displayed an impaired luminal uptake [16]. Intriguingly, DvSnf7 dsRNA resistant WCR also displayed cross resistance against three other dsRNA sequences but not to the Bacillus thuringiensis Cry3Bb1 protein [16].

Transgenic crops using RNAi may therefore be a promising tool when combined with other strategies for pest management. Bayer Crop Science and Corteva developed new transgenic lines expressing the combination of microbial compounds with RNAi targets $[150,151]$ (see the section below about pathogenic microbials). Large scale application and potential resistance development in the field have yet to be evaluated. Deployment of stacked dsRNA targeting immature and adult life stages might better capture WCR surviving single traits. However, efficacy of transgenic plants expressing dsRNA against adult WCR has not been thoroughly evaluated. 


\section{Enhancing Plant Health-Promoting Microbes}

Plant-insect-microbe interactions occurring in the rhizosphere can have dramatic effects across trophic levels, above and below ground, and can shape plant, herbivore, and microbial communities [152]. Beneficial microbial communities can provide plants with increased pest resistance [153]. Plants release a suite of chemicals from roots upon insect damage to which specific microbes respond. Over multiple generations, plants can then refine microbial communities that provide beneficial functions [154]. In the case of maize, benzoxazinoids have been shown to alter the rhizosphere microbiome, providing potential benefits to maize in the form of pest suppression in following generations [155]. Organic practices that promote soil health can also alter plant resistance to aboveground pest pressure [153]. However, there has been little work to investigate how these rhizosphere interactions affect western corn rootworm. Several groups are currently evaluating the potential of root-associated microbes to manage WCR. As a soil-dwelling root herbivore, WCR larvae are likely well adapted to maize rhizosphere microbial communities. Therefore, introducing non-native microbes that are compatible with maize, but not WCR physiology, may be a promising path.

Arbuscular mycorrhizal fungi (AMF) are one of the most integral groups of microorganisms promoting plant health. It is estimated $>80 \%$ of plant species form symbiotic relationships with AMF [156]. Plants associated with AMF exhibit increased nutrient absorption of $\mathrm{P}$ and other micronutrients [157]. AMF colonization can also increase induced jasmonic acid pathways involved in plant defense against herbivores [158]. However, predicting whether AMF colonization negatively or positively affects herbivore performance is complex [159]. A meta-analysis by Koricheva et al. [160] revealed chewing insects experience reduced performance on AMF associated plants while piercing-sucking insects experience an increase in performance. Many mechanisms are likely at play as AMF can reconfigure the plant primary and secondary metabolisms [161]. Jaffuel et al. [162] examined protection ability of a seven-species AMF seed treatment against WCR in the field. AMF treatment had no effect on root damage, WCR fitness, or yield. The extent of AMF association with roots was not measured, which makes predictions about AMF species effects difficult to interpret. Future investigations should consider promoting native AMF abundance and examine species-specific responses of WCR to AMF-colonized maize. Winter cover crops increase soil health by reducing erosion, limiting nutrient loss, and increasing microbial abundance and diversity $[163,164]$. Different species of cover crop can refine AMF and other microbial communities in distinct ways [165-168], and the legacy effects of cover crops can increase AMF colonization of cash crop roots [158,167]). Winter cover crops can also increase predator populations and correlate to reductions in root damage and WCR larvae [169]. This broader approach through ecological intensification could be employed by combining management techniques to sustainably manage populations and reduce damage. Work in this field is in its infancy but has potential to expand into new management applications.

\section{Using Soil Microbials to Disrupt WCR Gut Microbiome}

Douglas [170] theorized the exploitation of insect microbiomes could provide new pest management techniques. Studies have shown the western corn rootworm actively selects for microorganisms it harbors [171,172]. Larvae reared in two different soils harbor similar bacterial communities even though the soil samples vary widely in community composition [172]. The WCR bacterial community commonly consists of species of Serratia, Pseudomonas, Klebsiella, Acinetobactor, Streptomyces, and Tsukamurella, with other species appearing in high abundance but sporadically [171-174]. Studies have focused on surveying the bacterial community of WCR but have done little to try to characterize functionality of that community. Robert et al. [175] evaluated fitness of multigenerational antibiotictreated WCR and found no significant difference in weight gain or survival on conventional corn. Antibiotics were given to adults, and only the presence of Wolbachia was analyzed using PCR, so it is unclear what other bacteria remained after antibiotic treatment, or 
what bacteria were acquired from the soil during larval feeding. A majority of WCR populations also carry a high proportion of the maternally transmitted endosymbiont, Wolbachia $[171,172,176]$. Wolbachia can play an influential role in insect reproduction by inducing cytoplasmic incompatibility, parthenogenesis, feminization, and male killing [177]. Reproductive isolation caused by cytoplasmic incompatibility can result in speciation events at a much greater speed than traditional genetic elements $[178,179]$. Two subspecies of Diabrotica virgifera, D. v. virgifera (WCR) and D. v. zeae Krysan and Smith (Mexican corn rootworm), are a result of Wolbachia-induced cytoplasmic incompatibility that occurred after the ancestral population reached the area of modern-day Arizona less than 1100 years ago $[180,181]$. Wolbachia has also been shown to influence the composition of the host microbiome [182] and even protect the host from viral infection in populations of Drosophila melanogaster [183]. A role outside of reproductive incompatibility has not been found for Wolbachia in WCR. Wolbachia does appear to modulate plant gene expression, but this does not seem to impact major defenses or WCR resistance $[175,184]$. Nonetheless, it appears that some of the bacteria that inhabit WCR display functional capacity in overcoming plant defenses. Chu et al. [173] identified alterations in the gut microbial community of rotation-resistant populations of WCR. These shifts in the bacterial community were accompanied by increased cysteine protease activity in the gut that facilitated adult survival on soybean foliage [173]. In another study, bacterial isolates from abdomens of females influenced oviposition preference in choice tests [185]. The number of examples illustrating the role of the herbivore microbiome in overcoming plant defenses in other systems is increasing [186-189].

Mechanistic studies investigating the role of WCR gut microbiome in WCR ecological success are crucial to develop effective pest management strategies. A possible avenue would be to inoculate the soil with specific microbes that would shift WCR gut microbiome communities and hinder their ability to overcome plant defenses.

\section{Using Pathogenic Microbials to Reduce WCR Populations}

Management of arthropods through the use of microbes has a long history [190,191]. More recently, greater emphasis has been placed on limiting damage to non-target organisms and, in turn, has significantly increased the attractiveness of microbes as biocontrol agents. Classically, there are five main categories recognized under the term microbial control agents (MCAs): bacteria, viruses, fungi, protozoa, and nematodes [192]. Each has a unique mode of action and requires careful application to maximize benefit within the integrated pest management (IPM) framework. As advancements have been made in the microbial control of several pest species, their applications for WCR have mostly focused on transgenic approaches and entomopathogenic nematodes (EPNs).

The entomopathogenic bacteria from the genus Bacillus are some of the most widely used microbial biocontrol agents. These bacteria produce crystal toxins (Cry) that cause mortality in the insect by inducing cell lysis in the midgut [193]. Corn rootworm management has largely depended on Bacillus thuringiensis (Bt) for several decades through the planting of transgenic corn that express Cry toxins. There are currently four different Bt toxins commercially available as in-plant corn traits. In addition, Bayer Crop Science has developed SmartStax PRO expressing Cry3Bb1, Cry34Ab1/Cry35Ab1 and DvSnf7 (Diabrotica virgifera (Dv) + sucrose-non-fermenting (SNF) locus), a novel RNAibased trait which targets a specific RNA sequence of WCR [150]. This product is approved by the EPA and recently received import approval from China. These germplasm will be widely planted for the first time in 2022. Bayer also recently discovered an additional Bt protein [194] and a protein from Brevibacillus laterosporus [195], each with strong activity against western corn rootworm larvae and no cross resistance to current rootworm toxins. Corteva has a new transgenic maize line producing a toxin derived from Pseudomonas chlororaphis pyramided with dsRNA available [151], but the feasibility for large scale application has yet to be evaluated. Other toxins displaying activity against WCR have also been documented. These toxins were originally isolated from the ento- 
mopathogenic bacteria, Chromobacterium piscinae, Pseudomonas mosselii, Alcaligenes faecalis, Photorhabdus luminescens [196-199], and entomopathogenic fungi from the genus Pleurotus [200]. Examination of bacterial species that display toxicity in other Coleopteran species (Yersinia entomophaga, Paenobacillus spp., Serratia entomophila) are lacking for the western corn rootworm [191,201-203].

Entomopathogenic virus research has largely focused on the family Baculoviridae. This diverse viral family has shown promise as an MCA for Lepidopterans but seems to lack efficacy in Coleopterans. As such, Coleopteran viral research has focused on non-Baculoviridae species. Liu et al. [204-206] have identified two single-strand RNA viruses and an iflavirus present in WCR, but functional characterization has yet to be elucidated. Some success using virus as an MCA in beetles was demonstrated with the Oryctes rhinoceros nudivirus control coconut palm rhinoceros beetle (Oryctes rhinoceros) [207]. Fungi have also been under-evaluated as an MCA in corn rootworm. Strains of Metarhizium anisopliae, Beauveria bassiana, and Beauveria brongniartii display toxicity in larvae and adults [208], and M. anisopliae can significantly reduce adult emergence in field settings [209]. B. bassiana is commonly available as an MCA from several biopesticide companies, but it remains to be seen if treatments can be an economically viable control measure for WCR. Alternatively, both M. anisopliae and B. bassiana are found in agricultural soils and with proper soil management, could serve as a type of conservation biocontrol [210].

Entomopathogenic nematodes from the families Steinernematidae and Heterorhabditidae display high virulence against WCR [211] and, consequently, have been used to limit damage to maize infested with WCR $[162,212,213]$. Infective juveniles have a relatively short shelf life, making formulations difficult to use [214]. However, inducing a state of quiescence can prolong the infectiveness of EPN juveniles [215]. Root cap extracts of maize and pea contain potent amounts of quiescence factors that could be utilized to increase shelf life [216]. In addition, releases of nematodes for control rely on annual releases. No published studies have examined the long-term persistence of EPNs in WCR-maize systems, but such evidence exists in other systems [217]. Furthermore, field formulations and WCR specific strains show promising effects in the field and are available commercially [218-220].

Understanding the ecology of EPNs and identifying the infochemicals involved in their success will facilitate development of improved IPM strategies [221]. EPNs locate their host using universal, plant- and insect-derived chemical cues [222]. For instance, $H$. megidis can use the herbivore-induced root volatile (E)- $\beta$-caryophyllene [223] but see [224] Hiltpold et al. [225] showed that EPNs can be selected for increased responsiveness towards the terpenoid volatile within six generations. The enhanced EPN responsiveness to $(E)-\beta$ caryophyllene increased EPN success in controlling WCR populations, but only to maize hybrids that emit the volatile. H. bacteriophora is strongly attracted to WCR cadaver cues, such as butylated hydroxytoluene [226]. Interestingly, EPN-infected cadavers are not only attractive to EPNs but also to the herbivores themselves [226,227] and trigger a plant defensive response $[228,229]$.

WCR larvae can redirect plant defenses against nematodes [230]. Specifically, WCR larvae accumulate two benzoxazinoid glucosides: 6-methoxy-2-benzoxazolinone $\mathrm{N}$-glucoside (MBOA-Glc) and 2-hydroxy-4,7-dimethoxy-1,4-benzoxazin-3-one O-glucoside (HDMBOAGlc). MBOA-Glc is exuded by WCR onto its cuticle and is present in large amount in its frass [230]. This insect-specific detoxification benzoxazinone repels the EPN, H. bacteriophora. HDMBOA-Glc accumulates in the insect hemolymph and can be reactivated upon attack by nematodes to form MBOA [230], a toxic compound for both EPNs and their endosymbiotic bacteria [230]. By comparing EPN populations from the primary (US and Mexico) and invasive (Europe, Asia, Africa) ranges of the herbivore and conducting real-time selection assays, Zhang et al. [231] demonstrated that the herbivore adaptation to hijack plant defenses can shape the evolution of resistance in nematodes. Although $H$. bacteriophora EPNs from the invasive WCR range were again repelled by MBOA-Glc and susceptible to HDMBOA-Glc, EPNs from the original range of WCR were neither repelled nor susceptible to the sequestered compounds. Rearing a susceptible EPN strain 
in benzoxazinoid-sequestering hosts was sufficient for the nematode to evolve a complete resistance to benzoxazinoid-dependent defenses. The ability of EPNs to overcome these defenses was further associated with higher infectivity rates of WCR. Similarly, a screening of $H$. bacteriophora Mexican isolates showed that most were resistant to the benzoxazinoid defenses of WCR larvae [232]. Interestingly, the variability in infectiveness of these isolates in the benzoxazinoid-sequestering WCR larvae suggests other WCR defensive mechanisms may exist and require further investigation. The relative contribution of genetic variation and epigenetic effects in the nematodes and its endosymbionts is currently under investigation. Early results demonstrate that engineering bacterial symbionts that are resistant to the WCR benzoxazinoid-defenses can improve EPN infectivity [233]. Resistance to benzoxazinoids of five Photorhabdus strains was successfully enhanced through experimental evolution. Strikingly, the evolution of resistance was acquired through multiple mechanisms in the different bacterial strains, because the observed insertions and nonsynonymous point mutations did not overlap. The insertions and mutations were located in genes encoding for a DNA-directed RNA polymerase, a transcriptional regulator of porins, a regulator of unsaturated fatty acid biosynthesis, a ligase involved in the biosynthesis of the outer membrane, and in an aquaporin gene, aqpZ, involved in membrane permeability. Further characterization of aqpZ confirmed its impact in benzoxazinoid resistance, as complementation of the mutated strain with the wild-type gene restored the bacterial susceptibility to MBOA. Reestablishing symbiosis between EPNs and the enhanced Photorhabdus strains increased EPN infectivity towards WCR by over 50\%. Efforts are now underway to test this strategy in the field and to assess whether EPNs compatible with commercial application can be enhanced in this manner.

The growing body of literature documenting factors shaping EPN success in killing WCR larvae will surely enhance the efficacy of EPN-mediated strategies. Using attractant signals for EPNs may allow for the maintenance of elevated numbers of EPNs in the field. This solution was tested with transgenic maize plants that constitutively release (E)- $\beta$-caryophyllene, which resulted in effective WCR suppression in the presence of EPNs [234]. However, the overexpression of the associated terpene synthase also had a number of physiological and ecological costs [235]. Releasing the pure compound synthetically may be an alternative option, but the long-term impact of the sometimesdeceptive strategy requires careful investigation. Adding EPN-infected cadavers that attract both WCR larvae and EPNs [226,227] is a promising avenue, at least for high-value smaller fields. Placing EPN-infected cadavers in the field confers multiple advantages as the insect cadavers will provide the EPNs with shelter until favorable soil conditions are reached [236], thereby optimizing EPN survival, dispersal, and virulence after application $[237,238]$. In a greenhouse assay, Shapiro-Ilan et al. [238] demonstrated that the release of EPN-infected insect cadavers reduced the survival of the root weevil, D. abbreviates, and the black vine weevil, Otiorhynchus sulcatus, two times better than EPN suspensions within 7 days. The application of EPN-infected cadavers eliminated the herbivore population within 28 days, whereas EPN suspensions only reduced the herbivore populations by about $50 \%$. Because EPN-infected cadavers induce plant resistance against leaf pathogens through volatile chemical cues [228,229], this strategy may be valuable for IPM. Alternatively, it is possible to apply nematodes in encapsulated hydrocapsules containing EPN quiescence factors covered with herbivore attractants and feeding stimulants. Such a strategy would attract WCR larvae to feed on the capsules, thereby directly releasing EPNs [239,240]. When applied in the field, these hydrocapsules effectively controlled WCR populations and reduced damage [240]. Deployment of EPN-containing hydrocapsules for control also appears feasible in other herbivore species [220]. Finally, priming, selecting, or engineering EPNs for increased responsiveness to WCR-indicating chemical cues or for increased resistance to WCR defenses appears promising. Priming of EPNs can be achieved through exposure to insect cues, such as insect macerates or pheromones, prior to application in the field [241-243]. Selection of EPNs or their endosymbiotic bacteria for enhanced responsiveness or resistance to insect chemicals can be obtained within a few generations 
in laboratory conditions [231,233]. The growing understanding of EPN biology and of their interactions with prey will only enhance the efficacy of integrated pest management strategies in general.

\section{Conclusions}

Reliance on one dimensional management techniques has resulted in failures, both in terms of technologies and population suppression. In dealing with this established and persistent pest in the US and Europe, additional tools and a multifaceted approach to management are needed (Figure 1). The intense research involving WCR biology and chemical ecology has yielded knowledge that could translate into effective management strategies in the near- and long-term. Here, we reviewed a number of potential WCR management possibilities that, if implemented, have promise for new, effective, and sustainable WCR management. Results from lab-based studies sometimes fail to translate to field-based studies. Many of the strategies discussed here need additional testing in field settings under varying environmental conditions to properly assess their commercial viability but hold promise nonetheless.

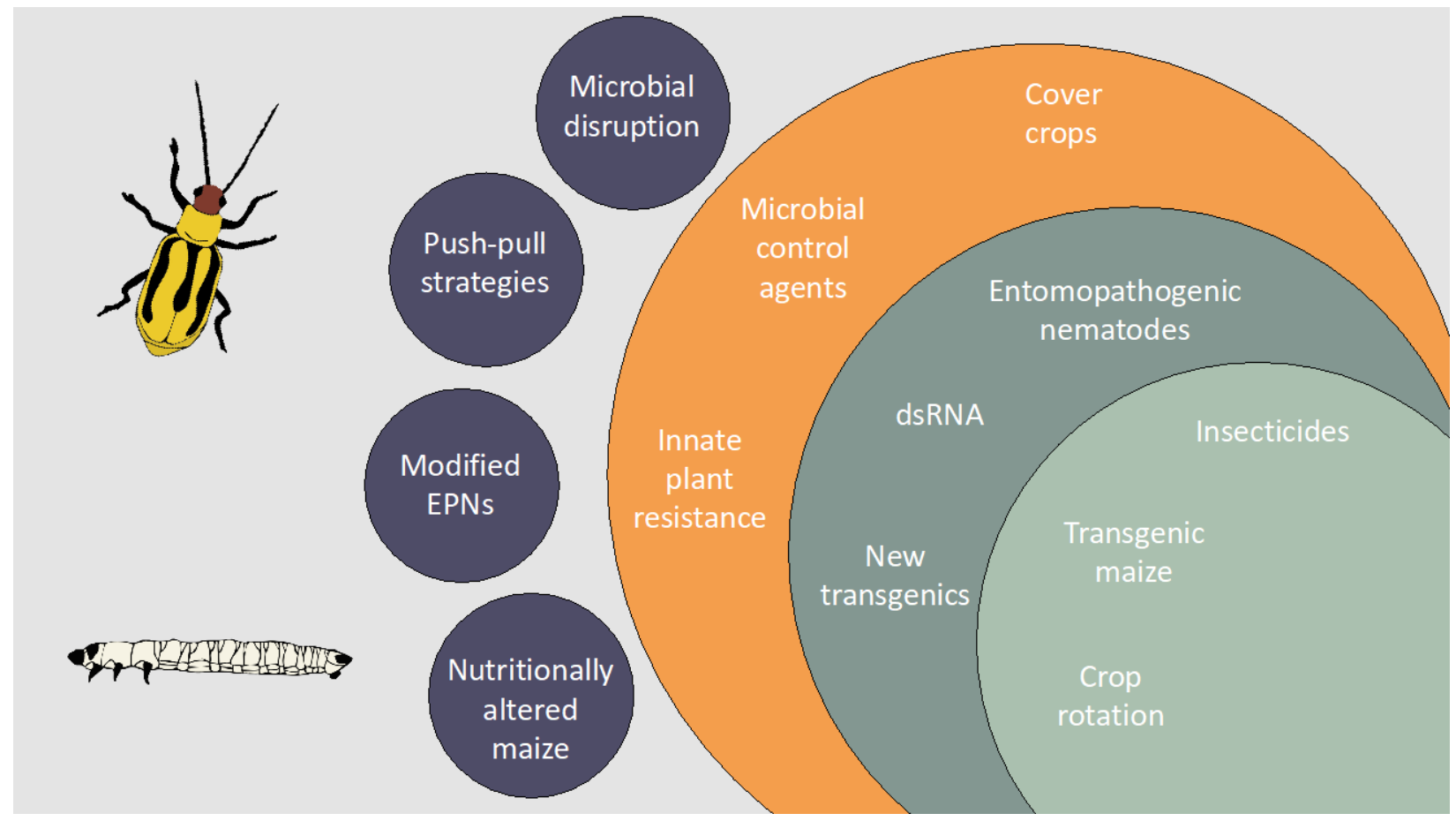

Figure 1. Broadening of management tactics aimed at controlling western corn rootworm (Diabrotica virgifera virgifera LeConte) and reducing damage to maize. The inner most circle (light green) represents the most common and widely adopted management techniques, all of which have seen failures in the field due to evolved resistance by western corn rootworm. The middle circle (dark green) represents management techniques less frequently adopted but have demonstrated effectiveness in laboratory or small field trials. The outermost circle (orange) represents management tactics that show promise and could be adopted using existing technology. Orbiting circles (blue) represent future management tactics that could be used if developed further.

Author Contributions: K.J.P., C.A.M.R., M.E., B.E.H. contributed to all drafts of the manuscript. All authors have read and agreed to the published version of the manuscript.

Funding: This research received no external funding.

Institutional Review Board Statement: Not applicable.

Data Availability Statement: Not applicable. 
Acknowledgments: The work of C.A.M. Robert was supported by the European Research Council (ERC) under the European Union's Horizon 2020 research and innovation program (grant agreement no. ERC-2020-STG 949595). The work of K.J. Paddock was supported by the University of Missouri Division of Plant Sciences and USDA-ARS. We thank the editor and three anonymous reviewers for their help in improving the manuscript.

Conflicts of Interest: Authors declare no conflict of interest.

\section{References}

1. Gillette, C.P. Diabrotica virgifera Lec. as a corn rootworm. J. Econ. Entomol. 1912, 5, 364-366. [CrossRef]

2. Metcalf, R.L. Foreword. In Methods for the Study of the Pest Diabrotica; Krysan, J.L., Miller, T.A., Eds.; Springer: New York, NY, USA, 1986; pp. 7-15.

3. Chiang, H.C. Bionomics of the northern and western corn rootworms. Annu. Rev. Entomol. 1973, 18, 47-72. [CrossRef]

4. Miller, N.; Estoup, A.; Toepfer, S.; Bourguet, D.; Lapchin, L.; Derridj, S.; Kim, K.S.; Reynaud, P.; Furlan, L.; Guillemaud, T. Multiple transatlantic introductions of the western corn rootworm. Science 2005, 310, 992. [CrossRef]

5. Wechsler, S.; Smith, D. Has resistance taken root in US corn fields? Demand for insect control. Am. J. Agric. Econ. 2018, 100, 1136-1150. [CrossRef]

6. Veres, A.; Wyckhuys, K.A.G.; Kiss, J.; Tóth, F.; Burgio, G.; Pons, X.; Avilla, C.; Vidal, S.; Razinger, J.; Bazok, R.; et al. An update of the Worldwide Integrated Assessment (WIA) on systemic pesticides. Part 4: Alternatives in major cropping systems. Environ. Sci. Pollut. Res. 2020, 27, 29867-29899. [CrossRef]

7. Robert, C.A.M.; Veyrat, N.; Glauser, G.; Marti, G.; Doyen, G.R.; Villard, N.; Gaillard, M.D.P.; Köllner, T.G.; Giron, D.; Body, M.; et al. A specialist root herbivore exploits defensive metabolites to locate nutritious tissues. Ecol. Lett. 2012, 15, 55-64. [CrossRef] [PubMed]

8. Ball, H.J.; Weekman, G.T. Insecticide resistance in the adult western corn rootworm in Nebraska. J. Econ. Entomol. 1962, 55, 439-441. [CrossRef]

9. Meinke, L.J.; Siegfried, B.D.; Wright, R.J.; Chandler, L.D. Adult susceptibility of Nebraska western corn rootworm (Coleoptera: Chrysomelidae) populations to selected insecticides. J. Econ. Entomol. 1998, 91, 594-600. [CrossRef]

10. Pereira, A.E.; Wang, H.; Zukoff, S.N.; Meinke, L.J.; French, B.W.; Siegfried, B.D. Evidence of field-evolved resistance to bifenthrin in western corn rootworm (Diabrotica virgifera virgifera LeConte) populations in western Nebraska and Kansas. PLoS ONE 2015, 10, e0142299. [CrossRef]

11. Meihls, L.N.; Higdon, M.L.; Siegfried, B.D.; Miller, N.J.; Sappington, T.W.; Ellersieck, M.R.; Spencer, T.A.; Hibbard, B.E. Increased survival of western corn rootworm on transgenic corn within three generations of on-plant greenhouse selection. Proc. Natl. Acad. Sci. USA 2008, 105, 19177. [CrossRef]

12. Meihls, L.N.; Higdon, M.L.; Ellersieck, M.; Hibbard, B.E. Selection for resistance to mCry3A-expressing transgenic corn in western corn rootworm. J. Econ. Entomol. 2011, 104, 1045-1054. [CrossRef] [PubMed]

13. Deitloff, J.; Dunbar, M.W.; Ingber, D.A.; Hibbard, B.E.; Gassmann, A.J. Effects of refuges on the evolution of resistance to transgenic corn by the western corn rootworm, Diabrotica virgifera virgifera LeConte. Pest Manag. Sci. 2016, 72, 190-198. [CrossRef] [PubMed]

14. Frank, D.L.; Zukoff, A.; Barry, J.; Higdon, M.L.; Hibbard, B.E. Development of resistance to eCry3.1Ab-expressing transgenic maize in a laboratory-selected population of western corn rootworm (Coleoptera: Chrysomelidae). J. Econ. Entomol. 2013, 106, 2506-2513. [CrossRef]

15. Levine, E.; Spencer, J.L.; Isard, S.A.; Onstad, D.W.; Gray, M.E. Adaptation of the western corn rootworm to crop rotation: Evolution of a new strain in response to a management practice. Am. Entomol. 2002, 48, 94-107. [CrossRef]

16. Khajuria, C.; Ivashuta, S.; Wiggins, E.; Flagel, L.; Moar, W.; Pleau, M.; Miller, K.; Zhang, Y.; Ramaseshadri, P.; Jiang, C.; et al. Development and characterization of the first dsRNA-resistant insect population from western corn rootworm, Diabrotica virgifera virgifera LeConte. PLoS ONE 2018, 13, 7059. [CrossRef]

17. Meinke, L.J.; Souza, D.; Siegfried, B.D. The Use of Insecticides to Manage the Western Corn Rootworm, Diabrotica virgifera virgifera, LeConte: History, Field-Evolved Resistance, and Associated Mechanisms. Insects 2021, 12, 112. [CrossRef]

18. EU No. 485. Available online: https:/ / eur-lex.europa.eu/eli/reg_impl/2013/485/oj (accessed on 15 January 2021).

19. Storer, N.P. A spatially explicit model simulating western corn rootworm (Coleoptera: Chrysomelidae) adaptation to insectresistant maize. J. Econ. Entomol. 2003, 5, 1530-1547. [CrossRef]

20. Hibbard, B.E.; Higdon, M.L.; Duran, D.P.; Schweikert, Y.M.; Ellersieck, M.R. Role of egg density on establishment and plant-toplant movement by western corn rootworm larvae (Coleoptera: Chrysomelidae). J. Econ. Entomol. 2004, 97, 871-882. [CrossRef]

21. Hibbard, B.E.; Meihls, L.N.; Ellersieck, M.R.; Onstad, D.W. Density-dependent and density-independent mortality of the western corn rootworm: Impact on dose calculations of rootworm-resistant Bt corn. J. Econ. Entomol. 2010, 103, 77-84. [CrossRef]

22. Strnad, S.P.; Bergman, M.K. Movement of first-instar western corn rootworms (Coleoptera: Chrysomelidae) in soil. Environ. Entomol. 1987, 4, 975-978. [CrossRef]

23. Ellsbury, M.M.; Schumacher, T.E.; Gustin, R.D.; Woodson, W.D. Soil compaction effect on corn rootworm populations in maize artificially infested with eggs of western corn rootworm (Coleoptera: Chrysomelidae). Environ. Entomol. 1994, 4, 943-948. [CrossRef]

24. Macdonald, P.J.; Ellis, C.R. Survival time of unfed, first-instar western corn rootworm (Coleoptera: Chrysomelidae) and the effects of soil type, moisture, and compaction on their mobility in soil. Environ. Entomol. 1990, 3, 666-671. [CrossRef] 
25. Chaddha, S. Influence of Placement of Western Corn Rootworm Eggs on Survivorship, Root Injury and Yield. Master's Thesis, University of Minnesota, Minneapolis, MN, USA, 1990.

26. Gustin, R.D.; Schumacher, T.E. Relationship of some soil pore parameters to movement of first-instar western corn rootworm (Coleoptera: Chrysomelidae). Environ. Entomol. 1989, 18, 343-346. [CrossRef]

27. Strnad, S.P.; Bergman, M.K. Distribution and orientation of western corn rootworm (Coleoptera: Chrysomelidae) larvae in corn roots. Environ. Entomol. 1987, 16, 1193-1198. [CrossRef]

28. Arce, C.C.M.; Theepan, V.; Schimmel, B.C.J.; Jaffuel, G.; Erb, M.; Machado, R.A.R. Plant-derived CO ${ }_{2}$ mediates long-distance host location and quality assessment by a root herbivore. BioRxiv 2020. [CrossRef]

29. Bernklau, E.J.; Bjostad, L.B. Behavioral responses of first-instar western corn rootworm (Coleoptera: Chrysomelidae) to carbon dioxide in a glass bead bioassay. J. Econ. Entomol. 1998, 91, 444-456. [CrossRef]

30. Bernklau, E.J.; Fromm, E.A.; Bjostad, L.B. Disruption of host location of western corn rootworm larvae (Coleoptera: Chrysomelidae) with carbon dioxide. J. Econ. Entomol. 2004, 97, 330-339. [CrossRef] [PubMed]

31. Schumann, M.; Patel, A.; Vidal, S. Soil application of an encapsulated $\mathrm{CO}_{2}$ source and its potential for management of western corn rootworm larvae. J. Econ. Entomol. 2014, 107, 230-239. [CrossRef] [PubMed]

32. Robert, C.A.M.; Erb, M.; Duployer, M.; Zwahlen, C.; Doyen, G.R.; Turlings, T.C.J. Herbivore-induced plant volatiles mediate host selection by a root herbivore. N. Phytol. 2012, 194, 1061-1069. [CrossRef]

33. Robert, C.A.M.; Erb, M.; Hibbard, B.E.; Wade French, B.; Zwahlen, C.; Turlings, T.C.J. A specialist root herbivore reduces plant resistance and uses an induced plant volatile to aggregate in a density-dependent manner. Funct. Ecol. 2012, 26, 1429-1440. [CrossRef]

34. Hiltpold, I.; Hibbard, B.E. Neonate larvae of the specialist herbivore Diabrotica virgifera virgifera do not exploit the defensive volatile (E)- $\beta$-caryophyllene in locating maize roots. J. Pest Sci. 2016, 89, 853-858. [CrossRef]

35. Strnad, S.P.; Dunn, P.E. Host search behaviour of neonate western corn rootworm (Diabrotica virgifera virgifera). J. Insect Physiol. 1990, 36, 201-205. [CrossRef]

36. Bernklau, E.J.; Hibbard, B.E.; Bjostad, L.B. Isolation and characterization of host recognition cues in corn roots for larvae of the western corn rootworm (Coleoptera: Chrysomelidae). J. Econ. Entomol. 2013, 106, 2354-2363. [CrossRef]

37. Bernklau, E.J.; Hibbard, B.E.; Dick, D.L.; Rithner, C.D.; Bjostad, L.B. Monogalactosyldiacylglycerols as host recognition cues for western corn rootworm larvae (Coleoptera: Chrysomelidae). J. Econ. Entomol. 2015, 108, 539-548. [CrossRef] [PubMed]

38. Bernklau, E.J.; Bjostad, L.B. Identification of feeding stimulants in corn roots for western corn rootworm (Coleoptera: Chrysomelidae) larvae. J. Econ. Entomol. 2008, 101, 341-351. [CrossRef]

39. Bernklau, E.J.; Hibbard, B.E.; Bjostad, L.B. Sugar preferences of western corn rootworm larvae in a feeding stimulant blend. J. Appl. Entomol. 2018, 142, 947-958. [CrossRef]

40. Bernklau, E.J.; Hibbard, B.E.; Bjostad, L.B. Toxic and behavioural effects of free fatty acids on western corn rootworm (Coleoptera: Chrysomelidae) larvae. J. Appl. Entomol. 2016, 140, 725-735. [CrossRef]

41. Hu, L.; Mateo, P.; Ye, M.; Zhang, X.; Berset, J.D.; Handrick, V.; Radisch, D.; Grabe, V.; Köllner, T.G.; Gershenzon, J.; et al. Plant iron acquisition strategy exploited by an insect herbivore. Science 2018, 361, 694-697. [CrossRef] [PubMed]

42. Machado, R.A.R.; Theepan, V.; Robert, C.A.M.; Züst, T.; Hu, L.; Su, Q.; Schimmel, B.C.J.; Erb, M. Complex plant metabolomes guide fitness-relevant foraging decisions of a specialist herbivore. BioRxiv 2020. [CrossRef]

43. Bernklau, E.J.; Hibbard, B.E.; Norton, A.P.; Bjostad, L.B. Methyl anthranilate as a repellent for western corn rootworm larvae (Coleoptera: Chrysomelidae). J. Econ. Entomol. 2016, 109, 1683-1690. [CrossRef]

44. Wouters, F.C.; Blanchette, B.; Gershenzon, J.; Vassão, D.G. Plant defense and herbivore counter-defense: Benzoxazinoids and insect herbivores. Phytochem. Rev. 2016, 15, 1127-1151. [CrossRef] [PubMed]

45. Bernklau, E.J.; Bjostad, L.B.; Hibbard, B.E. Synthetic feeding stimulants enhance insecticide activity against western corn rootworm larvae, Diabrotica virgifera virgifera (Coleoptera: Chrysomelidae). J. Appl. Entomol. 2011, 135, 47-54. [CrossRef]

46. Hibbard, B.E.; Peairs, F.B.; Pilcher, S.D.; Schroeder, M.E.; Jewett, D.K.; Bjostad, L.B. Germinating corn extracts and 6-methoxy-2benzoxazolinone: Western corn rootworm (Coleoptera: Chrysomelidae) larval attractants evaluated with soil insecticides. J. Econ. Entomol. 1995, 88, 716-724. [CrossRef]

47. Khan, Z.R.; Pickett, J.A. The "push-pull" strategy for stemborer management: A case study in exploiting biodiversity and chemical ecology. In Ecological Engineering for Pest Management: Advances in Habitat Manipulation for Arthropods; Gurr, G.M., Wratten, S.D., Altieri, M.A., Eds.; CABI: Oxon, UK, 2004; pp. 155-164.

48. Bernklau, E.J.; Hibbard, B.E.; Bjostad, L.B. Repellent effects of methyl anthranilate on western corn rootworm larvae (Coleoptera: Chrysomelidae) in soil bioassays. J. Econ. Entomol. 2019, 112, 683-690. [CrossRef] [PubMed]

49. Puebla, F.A.A.; Bernal, J.S. Resistance and tolerance to root herbivory in maize were mediated by domestication, spread, and breeding. Front. Plant Sci. 2020, 27, 223. [CrossRef]

50. Smith, C.M. Plant Resistance to Insects: A Fundamental Approach; Wiley: New York, NY, USA, 1989.

51. Painter, R.H. Insect Resistance in Crop Plants; Macmillian: New York, NY, USA, 1951. [CrossRef]

52. Howe, G.A.; Jander, G. Plant immunity to insect herbivores. Annu. Rev. Plant Biol. 2008, 59, 41-66. [CrossRef]

53. Loranger, J.; Meyer, S.T.; Shipley, B.; Kattge, J.; Loranger, H.; Roscher, C.; Weisser, W.W. Predicting invertebrate herbivory from plant traits: Evidence from 51 grassland species in experimental monocultures. Ecology 2012, 93, 2674-2682. [CrossRef] [PubMed]

54. Iason, G.R.; Dicke, M.; Hartley, S.E. The Ecology of Plant Secondary Metabolites: From Genes to Global Processes; Cambridge University Press: Cambridge, UK, 2012. 
55. Hanley, M.E.; Lamont, B.B.; Fairbanks, M.M.; Rafferty, C.M. Plant structural traits and their role in anti-herbivore defence. Perspect. Plant Ecol. Evol. Syst. 2007, 8, 157-178. [CrossRef]

56. Strauss, S.Y.; Agrawal, A.A. The ecology and evolution of plant tolerance to herbivory. Trends Ecol. Evol. 1999, 14, 179-185. [CrossRef]

57. Newingham, B.A.; Callaway, R.M.; Bassirirad, H. Allocating nitrogen away from a herbivore: A novel compensatory response to root herbivory. Oecologia 2007, 153, 913-920. [CrossRef]

58. Xue, K.; Serohijos, R.C.; Devare, M.; Duxbury, J.; Lauren, J.; Thies, J.E. Short-term carbon allocation and root lignin of Cry3Bb Bt and nonBt corn in the presence of corn rootworm. Appl. Soil Ecol. 2012, 57, 16-22. [CrossRef]

59. Robert, C.A.M.; Ferrieri, R.A.; Schirmer, S.; Babst, B.A.; Schueller, M.J.; Machado, R.A.R.; Arce, C.C.M.; Hibbard, B.E.; Gershenzon, J.; Turlings, T.C.J.; et al. Induced carbon reallocation and compensatory growth as root herbivore tolerance mechanisms. Plant Cell Environ. 2014, 37, 2613-2622. [CrossRef]

60. Robert, C.A.M.; Schirmer, S.; Barry, J.; French, W.B.; Hibbard, B.E.; Gershenzon, J. Belowground herbivore tolerance involves delayed overcompensatory root regrowth in maize. Entomol. Exp. Appl. 2015, 157, 113-120. [CrossRef]

61. Bigger, J.H.; Holbert, J.R.; Flint, W.P.; Lang, A.L. Resistance of certain corn hybrids to attack of southern corn rootworm. J. Econ. Entomol. 1938, 21, 103-107. [CrossRef]

62. Bigger, J.H.; Snelling, R.O.; Blanchard, R.A. Resistance of corn strains to the southern corn rootworm, Diabrotica duodecimpunctata F. J. Econ. Entomol. 1941, 34, 605-613. [CrossRef]

63. Wilson, R.L.; Peters, D.C. Plant Introductions of Zea mays as sources of corn rootworm tolerance. J. Econ. Entomol. 1973, 66, 101-104. [CrossRef]

64. Tollefson, J.J. Evaluating maize for resistance to Diabrotica virgifera virgifera Leconte (Coleoptera: Chrysomelidae). Maydica 2007, $52,311-318$.

65. Branson, T.F. Resistance in the grass tribe Maydeae to larvae of the western corn rootworm. Ann. Entomol. Soc. Am. 1971, 64, 861-863. [CrossRef]

66. Branson, T.F.; Guss, P.L. Potential for utilizing resistance from relatives of cultivated crops. Proc. North Cent. Branch Entomol. Soc. Am. 1972, 27, 91-95.

67. Branson, T.F.; Reyes, R.J. The Association of Diabrotica spp. with Zea diploperennis. J. Kans. Entomol. Soc. 1983, 56, 97-99.

68. Branson, T.F.; Fisher, J.R.; Kahler, A.L.; Sutter, G.R. Host plant resistance to corn rootworms. In Proceedings of the 17th Annual Illinois Corn Breeder School; Allerton House: Champaign, IL, USA, 1981.

69. Branson, T.F.; Sutter, G.R.; Fisher, J.R. Comparison of a tolerant and a susceptible maize inbred under artificial infestations of Diabrotica virgifera virgifera: Yield and adult emergence. Environ. Entomol. 1982, 11, 371-372. [CrossRef]

70. Branson, T.F. Larval feeding behavior and host-plant resistance in maize. In Methods for the Study of Pest Diabortica; Krysan, J.L., Miller, T.A., Eds.; Springer: New York, NY, USA, 1986; pp. 159-182.

71. Fitzgerald, P.J.; Ortman, E.E. Breeding for resistance to the western corn rootworm. In Proceedings of the Annual Hybrid Corn Industry Research Conference; Heckendorn, W., Sutherland, J.I., Eds.; American Seed Trade Association: Washington, DC, USA, 1964; pp. 46-60.

72. Fitzgerald, P.J.; Ortman, E.E. Two-year performance of inbreds and their single crosses grown under corn rootworm infestation. Proc. North Cent. Branch Entomol. Soc. Am. 1965, 20, 46-47.

73. Hills, T.M.; Peters, D.C. A method of evaluating postplanting insecticide treatments for control of western corn rootworm larvae. J. Econ. Entomol. 1971, 64, 764-765. [CrossRef]

74. Kahler, A.L.; Olness, A.E.; Sutter, G.R.; Dybing, C.D.; Devine, O.J. Root damage by western corn rootworm and nutrient content in maize. Agron. J. 1985, 77, 769-774. [CrossRef]

75. Kahler, A.L.; Telkamp, R.E.; Penny, L.H.; Branson, T.F.; Fitzgerald, P.J. Registration of NGSDCRW1(S2)C4 Maize Germplasm. Crop Sci. 1985, 25, 202. [CrossRef]

76. Ortman, E.E.; Gerloff, E.D. Rootworm resistance: Problems in measuring and its relationship to performance. In Proceedings of the 25th Annual Corn and Sorghum Research Conference, Washington, DC, USA, 8-10 December 1970; Sutherland, J.I., Falasca, R.J., Eds.; pp. 161-174.

77. Ortman, E.E.; Branson, T.F. Growth pouches for studies of host plant resistance to larvae of corn rootworms. J. Econ. Entomol. 1976, 69, 380-382. [CrossRef]

78. Ortman, E.E.; Branson, T.F.; Gerloff, E.D. Techniques, accomplishments, and future potential of host plant resistance to Diabrotica. In Proceedings of the Summer Institute on Biological Control of Plant Insects and Diseases; Maxwell, F.G., Harris, F.A., Eds.; University Press: Jackson, MS, USA, 1974; pp. 344-358.

79. Riedell, W.E. Western corn rootworm damage in maize: Greenhouse technique and plant response. Crop Sci. 1989, 29, 412-415. [CrossRef]

80. Riedell, W.E.; Evenson, P.D. Rootworm feeding tolerance in single-cross maize hybrids from different eras. Crop Sci. 1993, 33, 951-955. [CrossRef]

81. Prischmann, D.A.; Dashiell, K.E.; Schneider, D.J.; Hibbard, B.E. Field screening maize germplasm for resistance and tolerance to western corn rootworms (Col.: Chrysomelidae). J. Appl. Entomol. 2007, 131, 406-415. [CrossRef]

82. Assabgui, R.A.; Arnason, J.T.; Hamilton, R.I. Hydroxamic acid content in maize (Zea mays) roots of 18 Ontario recommended hybrids and prediction of antibiosis to the western corn rootworm, Diabrotica virgifera virgifera LeConte (Coleoptera: Chrysomelidae). Can. J. Plant Sci. 1993, 73, 359-363. [CrossRef] 
83. Assabgui, R.A.; Arnason, J.T.; Hamilton, R.I. Hydroxamic acid content and plant development of maize (Zea mays L.) in relation to damage by the western corn rootworm, Diabrotica virgifera virgifera LeConte. Can. J. Plant Sci. 1995, 75, 51-856. [CrossRef]

84. Rogers, R.R.; Owens, J.C.; Tollefson, J.J.; Witkowski, J.F. Evaluation of commercial corn hybrids for tolerance to corn rootworms. Environ. Entomol. 1975, 4. [CrossRef]

85. Assabgui, R.A.; Arnason, J.T.; Hamilton, R.I. Field evaluations of hydroxamic acids as antibiosis factors in elite maize inbreds to the western corn rootworm (Coleoptera: Chrysomelidae). J. Econ. Entomol. 1995, 88, 1482-1493. [CrossRef]

86. Xie, Y.S.; Arnason, J.T.; Philogene, B.J.R.; Lambert, J.D.H.; Atkinson, J.; Morand, P. Role of 2, 4-dihydroxy-7-methoxy-1, 4-benzoxazin-3-one (DIMBOA) in the resistance of maize to western corn rootworm, Diabrotica virgifera virgifera (Leconte) (Coleoptera: Chrysomelidae). Can. Entomol. 1990, 122, 1177-1186. [CrossRef]

87. Xie, Y.; Arnason, T.J.; Philogène, B.J.R.; Olechowski, H.T.; Hamilton, R. Variation of Hydroxamic acid content in maize roots in relation to geographic origin of maize germplasm and resistance to western corn rootworm (Coleoptera: Chrysomelidae). J. Econ. Entomol. 1992, 85, 2478-2485. [CrossRef]

88. Xie, Y.; Arnason, J.T.; Philogéne, B.J.R.; Atkinson, J.; Morand, P. Behavioral responses of western corn rootworm larvae to naturally occurring and synthetic hydroxamic acids. J. Chem. Ecol. 1992, 18, 945-957. [CrossRef] [PubMed]

89. Arnason, J.T.; Larsen, J.; Assabgui, R.; Xie, Y.; Atkinson, J.; Philogene, B.J.R.; Hamilton, R.I. Mechanisms of resistance in maize to western corn rootworm. In Insect resistant maize: Recent advances and utilization. In Proceedings of the International Symposium Held at the International Maize and Wheat Improvement Center (CIMMYT), El Bátan, Tunisia, 27 November-3 December 1994; pp. 96-100.

90. Moellenbeck, D.J.; Bergvinson, B.D.; Darrah, L.L. Advances in rating and phytochemical screening for corn rootworm resistance. In Insect resistant maize: Recent advances and utilization. In Proceedings of the International Symposium Held at the International Maize and Wheat Improvement Center (CIMMYT), El Bátan, Tunisia, 27 November-3 December 1994; pp. $203-210$.

91. Praiswater, T.W.; Hibbard, B.E.; Barry, B.D.; Darrah, L.L.; Smith, V.A. An implement for dislodging maize roots from the soil for corn rootworm (Coleoptera: Chrysomelidae) damage evaluations. J. Kans. Entomol. Soc. 1997, 70, 335-338. [CrossRef]

92. Hibbard, B.E.; Darrah, L.L.; Barry, B.D. Combining ability of resistance leads and identification of a new resistance source for western corn rootworm (Coleoptera: Chrysomelidae) larvae in corn. Maydica 1999, 44, 133-139.

93. Hibbard, B.E.; Barry, B.D.; Darrah, L.L.; Jackson, J.J.; Chandler, L.D.; French, L.K.; Mihm, J.A. Controlled field infestations with western corn rootworm (Coleoptera: Chrysomelidae) eggs in Missouri: Effects of egg strains, infestation dates, and infestation levels on corn root damage. J. Kans. Entomol. Soc. 1999, 72, 214-221. [CrossRef]

94. Hibbard, B.E.; Willmot, D.B.; Garcia, F.S.A.; Darrah, L.L. Registration of the maize germplasm CRW3(S1)C6 with resistance to western corn rootworm. J. Plant Regist. 2007, 1, 151-152. [CrossRef]

95. Rogers, R.R.; Russell, W.A.; Owens, J.C. Evaluation of a vertical-pull technique in population improvement of maize for corn rootworm tolerance. Crop Sci. 1976, 16, 591-594. [CrossRef]

96. Knutson, R.J.; Hibbard, B.E.; Barry, B.D.; Smith, V.A.; Darrah, L.L. Comparison of screening techniques for western corn rootworm (Coleoptera: Chrysomelidae) host-plant resistance. J. Econ. Entomol. 1999, 92, 714-722. [CrossRef]

97. Abel, C.A.; Berhow, M.A.; Wilson, R.L.; Binder, B.F.; Hibbard, B.E. Evaluation of conventional resistance to European corn borer (Lepidoptera: Crambidae) and western corn rootworm (Coleoptera: Chrysomelidae) in experimental maize lines developed from a backcross breeding program. J. Econ. Entomol. 2000, 93, 1814-1821. [CrossRef]

98. Garcia, F.S.A.; Dashiell, K.E.; Prischmann, D.A.; Bohn, M.O.; Hibbard, B.E. Conventional screening overlooks resistance sources: Rootworm damage of diverse inbred lines and their B73 hybrids is unrelated. J. Econ. Entomol. 2009, 102, 1317-1324. [CrossRef]

99. El Khishen, A.A.; Bohn, M.O.; Voldseth, P.D.A.; Dashiell, K.E.; French, B.W.; Hibbard, B.E. Native resistance to western corn rootworm (Coleoptera: Chrysomelidae) larval feeding: Characterization and mechanisms. J. Econ. Entomol. 2009, 102, 2350-2359. [CrossRef]

100. Bernklau, E.J.; Hibbard, B.E.; Bjostad, L.B. Antixenosis in maize reduces feeding by western corn rootworm larvae (Coleoptera: Chrysomelidae). J. Econ. Entomol. 2010, 103, 2052-2060. [CrossRef]

101. Šimić, D.; Ivezić, M.; Brkić, I.; Raspudić, E.; Brmež, M.; Majić, I.; Brkić, A.; Ledenčan, T.; Tollefson, J.J; Hibbard, B.E. Environmental and genotypic effects for western corn rootworm tolerance traits in American and European maize trials. Maydica 2007, 52, 425-430.

102. Ivezic, M.; Tollefson, J.J.; Raspudic, E.; Brkic, I.; Brmez, M.; Hibbard, B.E. Evaluation of corn hybrids for tolerance to corn rootworm (Diabrotica virgifera virgifera LeConte) larval feeding. Cereal Res. Commun. 2006, 34, 1101-1107. [CrossRef]

103. Ivezić, M.; Tollefson, J.J.; Raspudić, E.; Hibbard, B.E.; Brkić, I. Evaluation of Croation corn hybrids for tolerance to corn rootworm (Diabrotica virgifera virgifera LeConte) larval feeding. In Proceedings of the 21st IWGO Conference and VIII Diabrotica subgroup meeting, Venice, Italy, 27 October-3 November 2001; pp. 205-212.

104. Ivezić, M.; Raspudić, E.; Brmež, M.; Majić, I.; Brkić, I.; Tollefson, J.J.; Bohn, M.; Hibbard, B.E.; Šimić, D. A review of resistance breeding options targeting western corn rootworm (Diabrotica virgifera virgifera LeConte). Agric. For. Entomol. 2009, 11, 307-311. [CrossRef]

105. Bohn, M. How to improve rootworm resistance in corn. In Proceedings of the 41st Illinois Corn Breeders School; Illinois Corn Breeders School: Champaign-Urbana, IL, USA, 2005; pp. 183-194.

106. Rogers, R.R.; Russell, W.A.; Owens, J.C. Relationship of corn rootworm (Diabrotica) tolerance to yield in the Isss (Iowa stiff stalk synthetic) maize population. Iowa State J. Res. 1976, 51, 125-129. 
107. Bohn, M.O.; Marroquin, J.J.; Garcia, F.S.; Dashiell, K.; Willmot, D.B.; Hibbard, B.E. Quantitative trait loci mapping of western corn rootworm (Coleoptera: Chrysomelidae) host plant resistance in two populations of doubled haploid lines in maize (Zea mays L.). J. Econ. Entomol. 2018, 111, 435-444. [CrossRef]

108. Russell, W.A.; Owens, J.C.; Peters, D.C.; Rogers, R.R. Registration of maize germplasm 1 (Reg. Nos. GP 72 and GP 73 ). Crop Sci. 1976, 16, 886-887. [CrossRef]

109. Rogers, R.R.; Russell, W.A.; Owens, J.C. Expected gains from selection in maize for resistance to corn rootworms. Maydica 1977, $22,27-36$.

110. Russell, W.A.; Penny, L.H.; Guthrie, W.D.; Dicke, F.F. Registration of maize germplasm inbreds 1 (Reg. Nos. GP 1 to 5). Crop Sci. 1971, 11, 140. [CrossRef]

111. Russell, W.A.; Penny, L.H.; Sprague, G.F.; Guthrie, W.D.; Dicke, F.F. Registration of corn parental lines (Reg. nos. PL 1 to 13). Crop Sci. 1971, 11, 143. [CrossRef]

112. Owens, J.C.; Peters, D.C.; Hallauer, A.R. Corn rootworm tolerance in maize. Environ. Entomol. 1974, 3, 767-772. [CrossRef]

113. Branson, T.F.; Welch, V.A.; Sutter, G.R.; Fisher, J.R. Resistance to larvae of Diabrotica virgifera virgifera in three experimental maize hybrids. Environ. Entomol. 1983, 12, 1509-1512. [CrossRef]

114. Brkić, A.; Šimić, D.; Jambrović, A.; Zdunić, Z.; Ledençan, T.; Raspudić, E.; Brmeţ, M.; Brkić, J.; Mazur, M.; Galić, V. QTL analysis of western corn rootworm resistance traits in maize ibm population grown in continuous maize. Genetika 2020, 52, 137-148. [CrossRef]

115. Prasanna, B.M. Diversity in global maize germplasm: Characterization and utilization. J. Biosci. 2012, 37, 843-855. [CrossRef]

116. Meihls, L.N.; Kaur, H.; Jander, G. Natural variation in maize defense against insect herbivores. Cold Spring Harb. Symp. Quant. Biol. 2012, 77, 269-283. [CrossRef] [PubMed]

117. Mohan, S.; Ma, P.W.K.; Pechan, T.; Bassford, E.R.; Williams, W.P.; Luthe, D.S. Degradation of the S. frugiperda peritrophic matrix by an inducible maize cysteine protease. J. Insect Physiol. 2006, 52, 21-28. [CrossRef] [PubMed]

118. Mohan, S.; Ma, P.W.K.; Williams, W.P.; Luthe, D.S. A naturally occurring plant cysteine protease possesses remarkable toxicity against insect pests and synergizes Bacillus thuringiensis toxin. PLoS ONE 2008, 3, e1786. [CrossRef]

119. Duque, C.L.; Loades, K.W.; Tooker, J.F.; Brown, K.M.; Williams, P.W.; Luthe, D.S. A maize inbred exhibits resistance against western corn rootwoorm, Diabrotica virgifera virgifera. J. Chem. Ecol. 2017, 43, 1108-1123. [CrossRef]

120. Ramstein, G.P.; Jensen, S.E.; Buckler, E.S. Breaking the curse of dimensionality to identify causal variants in Breeding 4 . Theor. Appl. Genet. 2019, 132, 559-567. [CrossRef]

121. Branson, T.F.; Ortman, E.E. Host range of larvae of the western corn rootworm. J. Econ. Entomol. 1967, 60, 201-203. [CrossRef]

122. Branson, T.F.; Ortman, E.E. The host range of larvae of the western corn rootworm: Further studies. J. Econ. Entomol. 1970, 63, 800-803. [CrossRef]

123. Clark, T.L.; Hibbard, B.E. Comparison of nonmaize hosts to support western corn rootworm (Coleoptera: Chrysomelidae) larval biology. Environ. Entomol. 2004, 33, 681-689. [CrossRef]

124. Oyediran, I.O.; Hibbard, B.E.; Clark, T.L. Prairie grasses as hosts of the western corn rootworm (Coleoptera: Chrysomelidae). Environ. Entomol. 2004, 33, 740-747. [CrossRef]

125. Wilson, T.A.; Hibbard, B.E. Host suitability of nonmaize agroecosystem grasses for the western corn rootworm (Coleoptera: Chrysomelidae). Environ. Entomol. 2004, 33, 1102-1108. [CrossRef]

126. Moeser, J.; Vidal, S. How to measure the food utilization of subterranean insects: A case study with the western corn rootworm (Diabrotica virgifera virgifera). J. Appl. Entomol. 2005, 129, 60-63. [CrossRef]

127. Hibbard, B.E.; Schweikert, Y.M.; Higdon, M.L.; Ellersieck, M.R. Maize phenology affects establishment, damage, and development of the western corn rootworm (Coleoptera: Chrysomelidae). Environ. Entomol. 2008, 37, 1558-1564. [CrossRef] [PubMed]

128. Ritchie, W.S.; Hanway, J.J.; Benson, G.O. How a Corn Plant Develops; Iowa State University: Ames, IA, USA, 1992.

129. Law, J.H. Insects, oxygen, and iron. Biochem. Biophys. Res. Commun. 2002, 292, 1191-1195. [CrossRef]

130. Chege, P.G.; Clark, T.L.; Hibbard, B.E. Alternate host phenology affects survivorship, growth, and development of western corn rootworm (Coleoptera: Chrysomelidae) larvae. Environ. Entomol. 2005, 34, 1441-1447. [CrossRef]

131. Huynh, M.P.; Hibbard, B.E.; Vella, M.; Lapointe, S.L.; Niedz, R.P.; Shelby, K.S.; Coudron, T.A. Development of an improved and accessible diet for western corn rootworm larvae using response surface modeling. Sci. Rep. 2019, 9, 6009. [CrossRef] [PubMed]

132. Hannon, G.J. RNA interference. Nature 2002, 418, 244-251. [CrossRef]

133. Katoch, R.; Sethi, A.; Thakur, N.; Murdock, L.L. RNAi for insect control: Current perspective and future challenges. Appl. Biochem. Biotechnol. 2013, 171, 847-873. [CrossRef]

134. Ivashuta, S.; Zhang, Y.; Wiggins, B.E.; Ramaseshadri, P.; Segers, G.C.; Johnson, S.; Meyer, S.E.; Kerstetter, R.A.; McNulty, B.C.; Bolognesi, R.; et al. Environmental RNAi in herbivorous insects. RNA 2015, 21, 840-850. [CrossRef]

135. Turner, C.T.; Davy, M.W.; Diarmid, M.R.M.; Plummer, K.M.; Birch, N.P.; Newcomb, R.D. RNA interference in the light brown apple moth, Epiphyas postvittana (Walker) induced by double-stranded RNA feeding. Insect Mol. Biol. 2006, 15, 383-391. [CrossRef] [PubMed]

136. Rajagopal, R.; Sivakumar, S.; Agrawal, N.; Malhotra, P.; Bhatnagar, R.K. Silencing of midgut aminopeptidase N of Spodoptera litura by double-stranded RNA establishes its role as Bacillus thuringiensis toxin receptor. J. Biol. Chem. 2002, 6, 46849-46851. [CrossRef]

137. Bucher, G.; Scholten, J.; Klingler, M. Parental RNAi in tribolium (Coleoptera). Curr. Biol. 2002, 5, R85-R86. [CrossRef] 
138. Tomoyasu, Y.; Denell, R.E. Larval RNAi in Tribolium (Coleoptera) for analyzing adult development. Dev. Genes Evol. 2004, 214, 575-578. [CrossRef]

139. Soares, C.A.G.; Lima, C.M.R.; Dolan, M.C.; Piesman, J.; Beard, C.B.; Zeidner, N.S. Capillary feeding of specific dsRNA induces silencing of the isac gene in nymphal Ixodes scapularis ticks. Insect Mol. Biol. 2005, 14, 443-452. [CrossRef]

140. Baum, J.A.; Bogaert, T.; Clinton, W.; Heck, G.R.; Feldmann, P.; Ilagan, O.; Johnson, S.; Plaetinck, G.; Munyikwa, T.; Pleau, M.; et al. Control of coleopteran insect pests through RNA interference. Nat. Biotechnol. 2007, 25, 1322-1326. [CrossRef]

141. Bolognesi, R.; Ramaseshadri, P.; Anderson, J.; Bachman, P.; Clinton, W.; Flannagan, R.; Ilagan, O.; Lawrence, C.; Levine, S.; Moar, W.; et al. Characterizing the mechanism of action of double-stranded RNA activity against western corn rootworm (Diabrotica virgifera virgifera LeConte). PLoS ONE 2012, 7, e47534. [CrossRef]

142. Rangasamy, M.; Siegfried, B.D. Validation of RNA interference in western corn rootworm Diabrotica virgifera virgifera LeConte (Coleoptera: Chrysomelidae) adults. Pest Manag. Sci. 2012, 68, 587-591. [CrossRef] [PubMed]

143. Vélez, A.M.; Fishilevich, E.; Rangasamy, M.; Khajuria, C.; McCaskill, D.G.; Pereira, A.E.; Gandra, P.; Frey, M.L.F.; Worden, S.E.; Whitlock, S.L.; et al. Control of western corn rootworm via RNAi traits in maize: Lethal and sublethal effects of Sec23 dsRNA. Pest Manag. Sci. 2020, 76, 1500-1512. [CrossRef] [PubMed]

144. Khajuria, C.; Vélez, A.M.; Rangasamy, M.; Wang, H.; Fishilevich, E.; Frey, M.L.F.; Carneiro, N.P.; Gandra, P.; Narva, K.E.; Siegfried, B.D. Parental RNA interference of genes involved in embryonic development of the western corn rootworm, Diabrotica virgifera virgifera LeConte. Insect Biochem. Mol. Biol. 2015, 62, 54-62. [CrossRef]

145. Vélez, A.M.; Fishilevich, E.; Matz, N.; Storer, N.P.; Narva, K.E.; Siegfried, B.D. Parameters for successful parental RNAi as an insect pest management tool in western corn rootworm, Diabrotica virgifera virgifera. Genes 2017, 8, 7. [CrossRef]

146. Ramaseshadri, P.; Segers, G.; Flannagan, R.; Wiggins, E.; Clinton, W.; Ilagan, O.; McNulty, B.; Clark, T.; Bolognesi, R. Physiological and cellular responses caused by RNAi-mediated suppression of Snf7 orthologue in western corn rootworm (Diabrotica virgifera virgifera) larvae. PLoS ONE 2013, 8, e54270. [CrossRef]

147. Hu, X.; Richtman, N.M.; Zhao, J.Z.; Duncan, K.E.; Niu, X.; Procyk, L.A.; Oneal, M.A.; Kernodle, B.M.; Steimel, J.P.; Crane, V.C.; et al. Discovery of midgut genes for the RNA interference control of corn rootworm. Sci. Rep. 2016, 6, 542. [CrossRef]

148. Li, H.; Khajuria, C.; Rangasamy, M.; Gandra, P.; Fitter, M.; Geng, C.; Woosely, A.; Hasler, J.; Schulenberg, G.; Worden, S.; et al. Long dsRNA but not siRNA initiates RNAi in western corn rootworm larvae and adults. J. Appl. Entomol. 2015, 139, 432-445. [CrossRef]

149. Niu, X.; Kassa, A.; Hu, X.; Robeson, J.; McMahon, M.; Richtman, N.M.; Steimel, J.P.; Kernodle, B.M.; Crane, V.C.; Sandahl, G.; et al. Control of western corn rootworm (Diabrotica virgifera virgifera) reproduction through plant-mediated RNA interference. Sci. Rep. 2017, 7, 12591. [CrossRef] [PubMed]

150. Head, G.P.; Carroll, M.W.; Evans, S.P.; Rule, D.M.; Willse, A.R.; Clark, T.L.; Storer, N.P.; Flannagan, R.D.; Samuel, L.W.; Meinke, L.J. Evaluation of SmartStax and SmartStax PRO maize against western corn rootworm and northern corn rootworm: Efficacy and resistance management. Pest Manag. Sci. 2017, 73, 1883-1899. [CrossRef]

151. Anderson, J.A.; Mickelson, J.; Challender, M.; Moellring, E.; Sult, T.; TeRonde, S.; Walker, C.; Wang, Y.; Maxwell, C.A. Agronomic and compositional assessment of genetically modified DP23211 maize for corn rootworm control. GM Crop. Food 2020, 11, 206-214. [CrossRef]

152. Wardle, D.A.; Bardgett, R.D.; Klironomos, J.N.; Setälä, H.; Van Der Putten, W.H.; Wall, D.H. Ecological linkages between aboveground and belowground biota. Science 2004, 304, 1629-1633. [CrossRef] [PubMed]

153. Blundell, R.; Schmidt, J.E.; Igwe, A.; Cheung, A.L.; Vannette, R.L.; Gaudin, A.C.M.; Casteel, C.L. Organic management promotes natural pest control through altered plant resistance to insects. Nat. Plants 2020, 6, 483-491. [CrossRef]

154. Mueller, U.G.; Sachs, J.L. Engineering microbiomes to improve plant and animal health. Trends Microbiol. 2015, 23, 606-617. [CrossRef] [PubMed]

155. Hu, L.; Robert, C.A.M.; Cadot, S.; Zhang, X.; Ye, M.; Li, B.; Manzo, D.; Chervet, N.; Steinger, T.; Van Der Heijden, M.G.A.; et al. Root exudate metabolites drive plant-soil feedbacks on growth and defense by shaping the rhizosphere microbiota. Nat. Commun. 2018, 9, 2738. [CrossRef] [PubMed]

156. Willis, A.; Rodrigues, B.F.; Harris, P.J.C. The ecology of arbuscular mycorrhizal fungi. CRC Crit. Rev. Plant Sci. 2013, 32, 1-20. [CrossRef]

157. Javaid, A. Arbuscular mycorrhizal mediated nutrition in plants. J. Plant Nutr. 2009. [CrossRef]

158. Murrell, E.G.; Ray, S.; Lemmon, M.E.; Luthe, D.S.; Kaye, J.P. Cover crop species affect mycorrhizae-mediated nutrient uptake and pest resistance in maize. Renew. Agric. Food Syst. 2020, 35, 467-474. [CrossRef]

159. Gehring, C.; Bennett, A. Mycorrhizal fungal-plant-insect interactions: The importance of a community approach. Environ. Entomol. 2009, 38, 93-102. [CrossRef] [PubMed]

160. Koricheva, J.; Gange, A.C.; Jones, T. Effects of mycorrhizal fungi on insect herbivores: A meta-analysis. Ecology 2009, 90, $2088-2097$. [CrossRef] [PubMed]

161. Bennett, A.E.; Garcia, A.J.; Bever, J.D. Three-way interactions among mutualistic mycorrhizal fungi, plants, and plant enemies: Hypotheses and synthesis. Am. Nat. 2006, 167, 141-152. [CrossRef]

162. Jaffuel, G.; Imperiali, N.; Shelby, K.; Herrera, C.R.; Geisert, R.; Maurhofer, M.; Loper, J.; Keel, C.; Turlings, T.C.J.; Hibbard, B.E. Protecting maize from rootworm damage with the combined application of arbuscular mycorrhizal fungi, Pseudomonas bacteria and entomopathogenic nematodes. Sci. Rep. 2019, 9, 3127. [CrossRef] 
163. Vukicevich, E.; Lowery, T.; Bowen, P.; Torres, Ú.J.R.; Hart, M. Cover crops to increase soil microbial diversity and mitigate decline in perennial agriculture. A review. Agron. Sustain. Dev. 2016, 36, 48. [CrossRef]

164. Hartwig, N.L.; Ammon, H.U. Cover crops and living mulches. Weed Sci. 2002, 50, 688-699. [CrossRef]

165. Bainard, L.D.; Bainard, J.D.; Hamel, C.; Gan, Y. Spatial and temporal structuring of arbuscular mycorrhizal communities is differentially influenced by abiotic factors and host crop in a semi-arid prairie agroecosystem. FEMS Microbiol. Ecol. 2014, 88, 333-344. [CrossRef] [PubMed]

166. Benitez, M.S.; Taheri, W.I.; Lehman, R.M. Selection of fungi by candidate cover crops. Appl. Soil Ecol. 2016, 103, 72-82. [CrossRef]

167. Hontoria, C.; González, G.I.; Quemada, M.; Roldán, A.; Alguacil, M.M. The cover crop determines the AMF community composition in soil and in roots of maize after a ten-year continuous crop rotation. Sci. Total Environ. 2019, 660, 913-922. [CrossRef]

168. Cloutier, M.L.; Murrell, E.; Barbercheck, M.; Kaye, J.; Finney, D.; González, G.I.; Bruns, M.A. Fungal community shifts in soils with varied cover crop treatments and edaphic properties. Sci. Rep. 2020, 10, 6198. [CrossRef] [PubMed]

169. Lundgren, J.G.; Fergen, J.K. The effects of a winter cover crop on Diabrotica virgifera (Coleoptera: Chrysomelidae) populations and beneficial arthropod communities in no-till maize. Environ. Entomol. 2010, 39, 1816-1828. [CrossRef] [PubMed]

170. Douglas, A.E. Symbiotic microorganisms: Untapped resources for insect pest control. Trends Biotechnol. 2007, 25, 338-342. [CrossRef]

171. Dematheis, F.; Kurtz, B.; Vidal, S.; Smalla, K. Microbial communities associated with the larval gut and eggs of the western corn rootworm. PLoS ONE 2012, 7, 4685. [CrossRef]

172. Ludwick, D.C.; Ericsson, A.C.; Meihls, L.N.; Gregory, M.L.J.; Finke, D.L.; Coudron, T.A.; Hibbard, B.E.; Shelby, K.S. Survey of bacteria associated with western corn rootworm life stages reveals no difference between insects reared in different soils. Sci. Rep. 2019, 9, 1-11. [CrossRef] [PubMed]

173. Chu, C.C.; Spencer, J.L.; Curzi, M.J.; Zavala, J.A.; Seufferheld, M.J. Gut bacteria facilitate adaptation to crop rotation in the western corn rootworm. Proc. Natl. Acad. Sci. USA 2013, 110, 11917-11922. [CrossRef] [PubMed]

174. Perlatti, B.; Luiz, A.L.; Prieto, E.L.; Fernandes, J.B.; da Silva, M.F.d.G.F.; Ferreira, D.; Costa, E.N.; Júnior, B.A.L.; Forim, M.R. MALDI-TOF MS identification of microbiota associated with pest insect Diabrotica speciosa. Agric. For. Entomol. 2017, 19, 408-417. [CrossRef]

175. Robert, C.A.M.; Frank, D.L.; Leach, K.A.; Turlings, T.C.J.; Hibbard, B.E.; Erb, M. Direct and indirect plant defenses are not suppressed by endosymbionts of a specialist root herbivore. J. Chem. Ecol. 2013, 39, 507-515. [CrossRef]

176. Clark, T.L.; Meinke, L.J.; Skoda, S.R.; Foster, J.E. Occurrence of Wolbachia in selected Diabroticite (Coleoptera: Chrysomelidae) beetles. Ann. Entomol. Soc. Am. 2001, 94, 877-885. [CrossRef]

177. Werren, J.H.; Baldo, L.; Clark, M.E. Wolbachia: Master manipulators of invertebrate biology. Nat. Rev. Microbiol. 2008, 6, 741-751. [CrossRef]

178. Werren, J.H. Wolbachia and Speciation. In Endless Forms: Species and Speciation; Berlocher, S.H., Ed.; Oxford University Press: New York, NY, USA, 1998; pp. 245-260.

179. Bordenstein, S.R. Symbiosis and the origin of species. In Insect Symbiosis; CRC Press: Boca Raton, FL, USA, 2003 ; pp. $283-304$.

180. Giordano, R.; Jackson, J.J.; Robertson, H.M. The role of Wolbachia bacteria in reproductive incompatibilities and hybrid zones of Diabrotica beetles and Gryllus crickets. Proc. Natl. Acad. Sci. USA 1997, 94, 11439-11444. [CrossRef]

181. Lombaert, E.; Ciosi, M.; Miller, N.J.; Sappington, T.W.; Blin, A.; Guillemaud, T. Colonization history of the western corn rootworm (Diabrotica virgifera virgifera) in North America: Insights from random forest ABC using microsatellite data. Biol. Invasions 2018, 20, 665-677. [CrossRef]

182. Ye, Y.H.; Seleznev, A.; Flores, H.A.; Woolfit, M.; McGraw, E.A. Gut microbiota in Drosophila melanogaster interacts with Wolbachia but does not contribute to Wolbachia-mediated antiviral protection. J. Invertebr. Pathol. 2017, 143, 18-25. [CrossRef] [PubMed]

183. Hedges, L.M.; Brownlie, J.C.; O’Neill, S.L.; Johnson, K.N. Wolbachia and virus protection in insects. Science 2008, 322, 702. [CrossRef]

184. Barr, K.L.; Hearne, L.B.; Briesacher, S.; Clark, T.L.; Davis, G.E. Microbial symbionts in insects influence down-regulation of defense genes in maize. PLoS ONE 2010, 5, e11339. [CrossRef] [PubMed]

185. Lance, D.R. Odors influence choice of oviposition sites by Diabrotica virgifera virgifera (Coleoptera: Chrysomelidae). J. Chem. Ecol. 1992, 18, 1227-1237. [CrossRef] [PubMed]

186. Shukla, S.P.; Beran, F. Gut microbiota degrades toxic isothiocyanates in a flea beetle pest. Mol. Ecol. 2020, 29, 4692-4705. [CrossRef]

187. Itoh, H.; Tago, K.; Hayatsu, M.; Kikuchi, Y. Detoxifying symbiosis: Microbe-mediated detoxification of phytotoxins and pesticides in insects. Nat. Prod. Rep. 2018, 35, 434-454. [CrossRef]

188. van den Bosch, T.J.M.; Welte, C.U. Detoxifying symbionts in agriculturally important pest insects. Microb. Biotechnol. 2017, 10, 531-540. [CrossRef]

189. Hammer, T.J.; Bowers, M.D. Gut microbes may facilitate insect herbivory of chemically defended plants. Oecologia 2015, 179, 1-14. [CrossRef]

190. Steinhaus, E. Microbial Control-The emergence of an idea. Hilgardia 1956, 26, 107-160. [CrossRef]

191. Lacey, L.A.; Grzywacz, D.; Ilan, S.D.I.; Frutos, R.; Brownbridge, M.; Goettel, M.S. Insect pathogens as biological control agents: Back to the future. J. Invertebr. Pathol. 2015, 132, 1-41. [CrossRef] [PubMed]

192. Vega, F.; Kaya, H. (Eds.) Insect Pathology; Academic Press: San Diego, CA, USA, 2012; ISBN 9780123849847.

193. Knowles, B.H.; Ellar, D.J. Colloid-osmotic lysis is a general feature of the mechanism of action of Bacillus thuringiensis $\delta$-endotoxins with different insect specificity. BBA Gen. Subj. 1987, 924, 509-518. [CrossRef] 
194. Yin, Y.; Flasinski, S.; Moar, W.; Bowen, D.; Chay, C.; Milligan, J.; Kouadio, J.L.; Pan, A.; Werner, B.; Buckman, K.; et al. A new Bacillus thuringiensis protein for western corn rootworm control. PLoS ONE 2020, 15, e0242791. [CrossRef]

195. Bowen, D.; Yin, Y.; Flasinski, S.; Chay, C.; Bean, G.; Milligan, J.; Moar, W.; Pan, A.; Werner, B.; Buckman, K.; et al. Cry75Aa (Mpp75Aa) insecticidal proteins for controlling the western corn rootworm, Diabrotica virgifera virgifera, (Coleoptera: Chrysomelidae), isolated from the insect pathogenic bacteria Brevibacillus laterosporus. Appl. Environ. Microbiol. 2020. [CrossRef]

196. Sampson, K.; Zaitseva, J.; Stauffer, M.; Berg, V.B.; Guo, R.; Tomso, D.; McNulty, B.; Desai, N.; Balasubramanian, D. Discovery of a novel insecticidal protein from Chromobacterium piscinae, with activity against western corn rootworm, Diabrotica virgifera virgifera. J. Invertebr. Pathol. 2017, 142, 34-43. [CrossRef]

197. Wei, J.Z.; Rear, O.J.; Schellenberger, U.; Rosen, B.A.; Park, Y.J.; McDonald, M.J.; Zhu, G.; Xie, W.; Kassa, A.; Procyk, L.; et al. A selective insecticidal protein from Pseudomonas mosselii for corn rootworm control. Plant Biotechnol. J. 2018, 16, 649-659. [CrossRef]

198. Yalpani, N.; Altier, D.; Barry, J.; Kassa, A.; Nowatzki, T.M.; Sethi, A.; Zhao, J.Z.; Diehn, S.; Crane, V.; Sandahl, G.; et al. An Alcaligenes strain emulates Bacillus thuringiensis producing a binary protein that kills corn rootworm through a mechanism similar to Cry34Ab1/Cry35Ab1. Sci. Rep. 2017, 7, 3063. [CrossRef]

199. Bowling, A.J.; Pence, H.E.; Li, H.; Tan, S.Y.; Evans, S.L.; Narva, K.E. Histopathological effects of Bt and TcdA insecticidal proteins on the midgut epithelium of western corn rootworm larvae (Diabrotica virgifera virgifera). Toxins (Basel) 2017, 9, 156. [CrossRef] [PubMed]

200. Panevska, A.; Hodnik, V.; Skočaj, M.; Novak, M.; Modic, Š.; Pavlic, I.; Podržaj, S.; Zarić, M.; Resnik, N.; Maček, P.; et al Pore-forming protein complexes from Pleurotus mushrooms kill western corn rootworm and Colorado potato beetle through targeting membrane ceramide phosphoethanolamine. Sci. Rep. 2019, 9, 5073. [CrossRef]

201. Hurst, M.R.H.; van Koten, C.; Jackson, T.A. Pathology of Yersinia entomophaga MH96 towards Costelytra zealandica (Coleoptera; Scarabaeidae) larvae. J. Invertebr. Pathol. 2014, 115, 102-107. [CrossRef]

202. Ruiu, L.; Satta, A.; Floris, I. Emerging entomopathogenic bacteria for insect pest management. Bull. Insectology 2013, 66, 181-186.

203. Jackson, T.A.; Pearson, J.F.; Callaghan, O.M.; Mahanty, H.K.; Willocks, M.J. Pathogen to product - development of Serratia entomophila (Enterobacteriaceae) as a commercial biological control agent for the New Zealand grass grub (Costelytra zealandica). In Use of Pathogens in Scarab Management; Jackson, T.A., Glare, T.R., Eds.; Intercept Ltd.: Andover, MA, USA, 1992; pp. 191-198.

204. Liu, S.; Chen, Y.; Sappington, T.W.; Bonning, B.C. Genome sequence of a novel positive-sense, single-stranded RNA virus isolated from western corn rootworm, Diabrotica virgifera virgifera LeConte. Genome Announc. 2017, 5, 17. [CrossRef] [PubMed]

205. Liu, S.; Chen, Y.; Sappington, T.W.; Bonning, B.C. Genome sequence of the first coleopteran iflavirus isolated from western corn rootworm, Diabrotica virgifera virgifera LeConte. Genome Announc. 2017, 5, 16. [CrossRef]

206. Liu, S.; Chen, Y.; Sappington, T.W.; Bonning, B.C. Genome sequence of Diabrotica virgifera virgifera virus 2, a novel small RNA virus of the western corn rootworm, Diabrotica virgifera virgifera LeConte. Genome Announc. 2017, 5, 17. [CrossRef] [PubMed]

207. Huger, A.M. The Oryctes virus: Its detection, identification, and implementation in biological control of the coconut palm rhinoceros beetle, Oryctes rhinoceros (Coleoptera: Scarabaeidae). J Invertebr. Pathol. 2005, 89, 78-84. [CrossRef]

208. Pilz, C.; Wegensteiner, R.; Keller, S. Selection of entomopathogenic fungi for the control of the western corn rootworm Diabrotica virgifera virgifera. J. Appl. Entomol. 2007, 131, 426-431. [CrossRef]

209. Pilz, C.; Keller, S.; Kuhlmann, U.; Toepfer, S. Comparative efficacy assessment of fungi, nematodes and insecticides to control western corn rootworm larvae in maize. BioControl 2009, 54, 671-684. [CrossRef]

210. Meyling, N.V.; Eilenberg, J. Ecology of the entomopathogenic fungi Beauveria bassiana and Metarhizium anisopliae in temperate agroecosystems: Potential for conservation biological control. Biol. Control 2007, 43, 145-155. [CrossRef]

211. Toepfer, S.; Gueldenzoph, C.; Ehlers, R.U.; Kuhlmann, U. Screening of entomopathogenic nematodes for virulence against the invasive western corn rootworm, Diabrotica virgifera virgifera (Coleoptera: Chrysomelidae) in Europe. Bull. Entomol. Res. 2005, 95, 473-482. [CrossRef]

212. Kurtz, B.; Toepfer, S.; Ehlers, R.U.; Kuhlmann, U. Assessment of establishment and persistence of entomopathogenic nematodes for biological control of western corn rootworm. J. Appl. Entomol. 2007, 131, 420-425. [CrossRef]

213. Kurtz, B.; Hiltpold, I.; Turlings, T.C.J.; Kuhlmann, U.; Toepfer, S. Comparative susceptibility of larval instars and pupae of the western corn rootworm to infection by three entomopathogenic nematodes. BioControl 2009, 54, 255. [CrossRef]

214. Ilan, S.D.I.; Gouge, D.H.; Piggott, S.J.; Fife, J.P. Application technology and environmental considerations for use of entomopathogenic nematodes in biological control. Biol. Control 2006, 38, 124-133. [CrossRef]

215. Hiltpold, I.; Jaffuel, G.; Turlings, T.C.J. The dual effects of root-cap exudates on nematodes: From quiescence in plant-parasitic nematodes to frenzy in entomopathogenic nematodes. J. Exp. Bot. 2015, 66, 603-611. [CrossRef]

216. Jaffuel, G.; Hiltpold, I.; Turlings, T.C.J. Highly potent extracts from pea (Pisum sativum) and maize (Zea mays) roots can be used to induce quiescence in entomopathogenic nematodes. J. Chem. Ecol. 2015, 41, 793-800. [CrossRef]

217. Shields, E.J.; Testa, A.M.; Neil, O.W.J. Long-term Persistence of Native New York Entomopathogenic Nematode Isolates Across Crop Rotation. J. Econ. Entomol. 2018, 111, 2592-2598. [CrossRef]

218. Ehlers Ralf, U.; Hiltpold, I.; Kulhmann, U.; Toepfer, S. Field results on the use of Heterorhabditis bacteriophage against the invasive maize pest Diabrotica virgifera virgeifera. Insect Pathog. Insect Parasit Nematodes 2008, 31, 332-335.

219. Toepfer, S.; Peters, A.; Ehlers, R.U.; Kuhlmann, U. Comparative assessment of the efficacy of entomopathogenic nematode species at reducing western corn rootworm larvae and root damage in maize. J. Appl. Entomol. 2008, 132, 337-348. [CrossRef] 
220. Jaffuel, G.; Sbaiti, I.; Turlings, T.C.J. Encapsulated entomopathogenic nematodes can protect maize plants from Diabrotica balteata larvae. Insects 2020, 11, 27. [CrossRef]

221. Griffin, C.T. Perspectives on the behavior of entomopathogenic nematodes from dispersal to reproduction: Traits contributing to nematode fitness and biocontrol efficacy. J Nematol. 2012, 44, 177-184.

222. Dillman, A.R.; Guillermin, M.L.; Lee, J.H.; Kim, B.; Sternberg, P.W.; Hallem, E.A. Olfaction shapes host-parasite interactions in parasitic nematodes. Proc. Natl. Acad. Sci. USA 2012, 109, E2324-E2333. [CrossRef] [PubMed]

223. Rasmann, S.; Köllner, T.G.; Degenhardt, J.; Hiltpold, I.; Toepfer, S.; Kuhlmann, U.; Gershenzon, J.; Turlings, T.C.J. Recruitment of entomopathogenic nematodes by insect-damaged maize roots. Nature 2005, 434, 732-737. [CrossRef] [PubMed]

224. Anbesse, S.; Ehlers, R.U. Attraction of Heterorhabditis sp. toward synthetic (E)-beta-cariophyllene, a plant SOS signal emitted by maize on feeding by larvae of Diabrotica virgifera virgifera. Commun. Agric. Appl. Biol. Sci. 2010, 75, 455-458.

225. Hiltpold, I.; Baroni, M.; Toepfer, S.; Kuhlmann, U.; Turlings, T.C.J. Selection of entomopathogenic nematodes for enhanced responsiveness to a volatile root signal helps to control a major root pest. J. Exp. Biol. 2010, 213, 2417-2423. [CrossRef]

226. Zhang, X.; Machado, R.A.R.; Van Doan, C.; Arce, C.C.M.; Hu, L.; Robert, C.A.M. Entomopathogenic nematodes increase predation success by inducing cadaver volatiles that attract healthy herbivores. eLife 2019, 8, 6668. [CrossRef] [PubMed]

227. Baiocchi, T.; Lee, G.; Choe, D.H.; Dillman, A.R. Host seeking parasitic nematodes use specific odors to assess host resources. Sci. Rep. 2017, 7, 6270. [CrossRef]

228. Jagdale, G.B.; Kamoun, S.; Grewal, P.S. Entomopathogenic nematodes induce components of systemic resistance in plants: Biochemical and molecular evidence. Biol. Control 2009, 51, 102-109. [CrossRef]

229. Helms, A.M.; Ray, S.; Matulis, N.L.; Kuzemchak, M.C.; Grisales, W.; Tooker, J.F.; Ali, J.G. Chemical cues linked to risk: Cues from below-ground natural enemies enhance plant defences and influence herbivore behaviour and performance. Funct. Ecol. 2019, 33, 798-808. [CrossRef]

230. Robert, C.A.M.; Zhang, X.; Machado, R.A.R.; Schirmer, S.; Lori, M.; Mateo, P.; Erb, M.; Gershenzon, J. Sequestration and activation of plant toxins protect the western corn rootworm from enemies at multiple trophic levels. eLife 2017, 6, 9307. [CrossRef] [PubMed]

231. Zhang, X.; Van Doan, C.; Arce, C.C.M.; Hu, L.; Gruenig, S.; Parisod, C.; Hibbard, B.E.; Hervé, M.R.; Nielson, C.; Robert, C.A.M.; et al. Plant defense resistance in natural enemies of a specialist insect herbivore. Proc. Natl. Acad. Sci. USA 2019, 116, 23174-23181. [CrossRef] [PubMed]

232. Bruno, P.; Machado, R.A.R.; Glauser, G.; Köhler, A.; Herrera, C.R.; Bernal, J.; Toepfer, S.; Erb, M.; Robert, C.A.M.; Arce, C.C.M.; et al. Entomopathogenic nematodes from Mexico that can overcome the resistance mechanisms of the western corn rootworm. Sci. Rep. 2020, 10, 8257. [CrossRef] [PubMed]

233. Machado, R.A.R.; Thönen, L.; Arce, C.C.M.; Theepan, V.; Prada, F.; Wüthrich, D.; Robert, C.A.M.; Vogiatzaki, E.; Shi, Y.M.; Schaeren, O.P.; et al. Engineering bacterial symbionts of nematodes improves their biocontrol potential to counter the western corn rootworm. Nat. Biotechnol. 2020, 38, 600-608. [CrossRef]

234. Degenhardt, J.; Hiltpold, I.; Köllner, T.G.; Frey, M.; Gierl, A.; Gershenzon, J.; Hibbard, B.E.; Ellersieck, M.R.; Turlings, T.C.J. Restoring a maize root signal that attracts insect-killing nematodes to control a major pest. Proc. Natl. Acad. Sci. USA 2009, 106, 13213-13218. [CrossRef]

235. Robert, C.A.M.; Erb, M.; Hiltpold, I.; Hibbard, B.E.; Gaillard, M.D.P.; Bilat, J.; Degenhardt, J.; Cambet, P.J.X.; Turlings, T.C.J.; Zwahlen, C. Genetically engineered maize plants reveal distinct costs and benefits of constitutive volatile emissions in the field. Plant Biotechnol. J. 2013, 11, 628-639. [CrossRef] [PubMed]

236. Lewis, E.E.; Ilan, S.D.I. Host cadavers protect entomopathogenic nematodes during freezing. J. Invertebr. Pathol. 2002, 81, 25-32. [CrossRef]

237. Ilan, S.D.I.; Brown, I. Earthworms as phoretic hosts for Steinernema carpocapsae and Beauveria bassiana: Implications for enhanced biological control. Biol. Control 2013, 66, 41-48. [CrossRef]

238. Ilan, S.D.I.; Lewis, E.E.; Son, Y.; Tedders, W.L. Superior efficacy observed in entomopathogenic nematodes applied in infected-host cadavers compared with application in aqueous suspension. J. Invertebr. Pathol. 2003, 83, 270-272. [CrossRef]

239. Kaya, H.K.; Nelsen, C.E. Encapsulation of Steinernematid and Heterorhabditid nematodes with calcium alginate: A new approach for insect control and other applications. Environ. Entomol. 1985, 14, 572-574. [CrossRef]

240. Hiltpold, I.; Hibbard, B.E.; French, B.W.; Turlings, T.C.J. Capsules containing entomopathogenic nematodes as a Trojan horse approach to control the western corn rootworm. Plant Soil 2012, 358, 11-25. [CrossRef]

241. Wu, S.; Kaplan, F.; Lewis, E.; Alborn, H.T.; Ilan, S.D.I. Infected host macerate enhances entomopathogenic nematode movement towards hosts and infectivity in a soil profile. J. Invertebr. Pathol. 2018, 159, 141-144. [CrossRef]

242. Ilan, S.D.I.; Kaplan, F.; Hofman, O.C.; Schliekelman, P.; Alborn, H.T.; Lewis, E.E. Conspecific pheromone extracts enhance entomopathogenic infectivity. J. Nematol. 2019, 51, 1-5. [CrossRef]

243. Hofman, O.C.; Kaplan, F.; Stevens, G.; Lewis, E.; Wu, S.; Alborn, H.T.; Gentil, P.A.; Ilan, S.D.I. Pheromone extracts act as boosters for entomopathogenic nematodes efficacy. J. Invertebr. Pathol. 2019, 164, 38-42. [CrossRef] [PubMed] 